\title{
Secondary Metabolites of Marine Microbes: From Natural Products Chemistry to Chemical Ecology
}

\author{
Lars-Erik Petersen, Matthias Y. Kellermann, \\ and Peter J. Schupp
}

\begin{abstract}
Marine natural products (MNPs) exhibit a wide range of pharmaceutically relevant bioactivities, including antibiotic, antiviral, anticancer, or anti-inflammatory properties. Besides marine macroorganisms such as sponges, algae, or corals, specifically marine bacteria and fungi have shown to produce novel secondary metabolites (SMs) with unique and diverse chemical structures that may hold the key for the development of novel drugs or drug leads. Apart from highlighting their potential benefit to humankind, this review is focusing on the manifold functions of SMs in the marine ecosystem. For example, potent MNPs have the ability to exile predators and competing organisms, act as attractants for mating purposes, or serve as dye for the expulsion or attraction of other organisms. A large compilation of literature on the role of MNPs in marine ecology is available, and several reviews evaluated the function of MNPs for the aforementioned topics. Therefore, we focused the second part of this review on the importance of bioactive compounds from crustose coralline algae (CCA) and their role during coral settlement, a topic that has received less attention. It has been shown that certain SMs derived from CCA and their associated bacteria are able to induce attachment and/or metamorphosis of many benthic invertebrate larvae, including globally threatened reef-building scleractinian corals. This review provides an overview on bioactivities of MNPs from marine microbes and their potential use in medicine as well as on the latest findings of the chemical ecology and settlement process of scleractinian corals and other invertebrate larvae.
\end{abstract}

\section{Keywords}

Marine natural products - Secondary metabolites .

Marine bacteria $\cdot$ Marine fungi $\cdot$ Crustose coralline algae

- Settlement · Coral larvae

\subsection{Introduction: Definition of Secondary Metabolism}

Over millions of years, evolution has created a multitude of diverse organisms and biocoenosis. Besides individual differences within their appearance and way of life, the ability of absorbing, processing, and secreting substances from and into the environment can be found in all living organisms (Madigan et al. 2003). The biosynthesis and breakdown of these substances, including proteins, fats, or nucleic acids, is commonly known as primary metabolism with the compounds involved known as "primary metabolites" (Dewick 2002; Dias et al. 2012). The primary metabolism of plants, animals, humans, and prokaryotic microorganisms shows great similarity and displays the essential uniformity of all living matters; it thus serves as a driving force for the survival and reproduction of all life (Kreis 2007). In contrast, the mechanism by which an organism synthesizes "secondary metabolites" (SMs), frequently associated with the term "natural products" (NPs), is known as secondary metabolism (Dias et al. 2012). SMs are defined as molecules with a molecular weight ranging between 100 and $1000 \mathrm{Da}$ (Breinbauer et al. 2002) and, unlike primary metabolites, are

P. J. Schupp $(\bowtie)$

Institute of Chemistry and Biology of the Marine Environment, University of Oldenburg, Oldenburg, Germany

Helmholtz Institute for Functional Marine Biodiversity at the University of Oldenburg (HIFMB), Oldenburg, Germany e-mail: peter.schupp@uni-oldenburg.de
L.-E. Petersen $(\square) \cdot$ M. Y. Kellermann

Institute of Chemistry and Biology of the Marine Environment,

University of Oldenburg, Oldenburg, Germany

e-mail: lars-erik.petersen1@ uni-oldenburg.de 
often found to be unique to an organism or a specific taxonomic group. They do not directly contribute to the basal metabolism of its producing organism but rather act as crucial factors to either attract, deter, or kill other organisms and thus increase their likelihood of survival (Kreysa and Grabley 2007). For example, SMs have been found in both prokaryotic and eukaryotic microorganisms, with unicellular bacteria (e.g., Bacillus spp., Pseudomonas spp.), eukaryotic fungi (e.g., Penicillium spp., Aspergillus spp.), filamentous actinomyces (e.g., Streptomyces spp.), and terrestrial plants being the most frequently studied and versatile producers (Bérdy 2005). Many SMs are only produced under specific circumstances to serve different purposes: they can exile predators or competing organisms because of their toxic nature (Dewick 2002), act as attractants toward the same species for mating purposes (Gurnani et al. 2014), or serve as dyes for the expulsion and attraction of other creatures (Pichersky and Gang 2000). A possible explanation why organisms produce a high variety of bioactive SMs is that these molecules provide producers with a selective advantage against competing organisms and, furthermore, act as an adaptation to environmental conditions (Jensen et al. 2005; O'Brien and Wright 2011; Letzel et al. 2013; Macheleidt et al. 2016). Moreover, several natural products (NPs) have the ability to protect against nonbiological impacts, such as high light intensities or elevated temperatures, and to obtain reproduction advantages for their producers (Ludwig-Müller and Gutzeit 2014). In the marine environment, SMs fulfill manifold tasks for their producers as they, for instance, act as a chemical defense against predators (Rohde et al. 2015; Helber et al. 2017; Rohde and Schupp 2018) or have antimicrobial effects against pathogenic microbes (Goecke et al. 2010; Rohde et al. 2015; Helber et al. 2018). Furthermore, MNPs are important for inducing larval settlement of benthic invertebrates (Yvin et al. 1985; Morse et al. 1988; Tebben et al. 2011, 2015; Harder et al. 2018), thereby maintaining and controlling community functioning and population dynamics. Besides their ecological impact, many NPs have been reported to exhibit a wide range of medically relevant bioactivities (Keller et al. 2005; Blunt et al. 2018), thus serving as promising molecules for the development of new drugs or drug leads (Heilmann 2007).

\subsection{Marine Natural Products Chemistry: The Ocean as a Rich and Versatile Habitat}

The ocean covers more than $70 \%$ of our planet's surface and likely represents the origin of Earth's life. In terms of species diversity, certain marine ecosystems, such as coral reefs, are thought to outnumber even tropical rain forests (Haefner 2003). Until today, the number of marine species that inhabit the world's oceans is not truly known; however, experts estimated a number approaching 1-2 million species (Simmons et al. 2005; Das et al. 2006). In the past, marine sponges were an interesting source for novel NPs; these sessile organisms can produce bioactive substances for chemical defense against natural predators, such as fishes (Rohde et al. 2015), as well as prevent overgrowth by competing organisms (Proksch 1994; Ortlepp et al. 2006). Furthermore, sponges serve as incubators for particular associated microorganisms like bacteria and fungi that also can contribute to the production of bioactive compounds (Radjasa et al. 2011; Wiese et al. 2011). Sponges being sessile, soft-bodied organisms, which mostly lack morphological defenses like biological armature or spines, depend to a large extend on bioactive metabolites for their survival and the survival of their associated microbial symbionts (Proksch et al. 2006). Accordingly, marine NP research has its origin in the discovery of the two nucleosides spongothymidine and spongouridine by Bergmann and coworkers in the 1950s, who isolated both active compounds from the Caribbean sponge Cryptotethya crypta (Bergmann and Feeneyz 1951; Bergmann and Burke 1955). These two SMs served as lead structures for the development of the synthetic antivirals cytarabine (Fig. 8.1a) and vidarabine (Fig. 8.1b) (Mayer et al. 2010) and, therefore, display exemplarily the tremendous potential of MNPs for the development of new drugs (Gulder and Moore 2009). Although promising and still relevant, sponges and their associated microorganisms are not the only marine source producing bioactive compounds. Marine NP research has expanded its efforts in exploring worldwide oceans and their inhabitants from macro- to microorganisms as rich sources for novel SMs. Until today, this resulted in new MNPs being continuously described (Table 8.1) (Martins et al. 2014). For instance, 1163 novel compounds derived from marine organisms were described only in 2013 (Blunt et al. 2015).

Over the past decades, it has been obvious that unknown NPs are more likely found when high quality materials from novel sources are examined (Goodfellow and Fiedler 2010). Unfortunately, the acquisition of marine organisms, compared to that of terrestrial organisms, is often more difficult and thus making the exploration and collection of marine samples (i.e., deep-sea organisms) very expensive (Molinski et al. 2009). However, past progress in marine technologies, such as easy accessible scuba diving equipment as well as remotely operated vehicles (ROVs), facilitated the investigations beyond the intertidal areas and led to the exploration of new marine organisms that can potentially produce a huge range of novel chemical compounds with unique bioactivities (Gerwick and Moore 2012). Since many MNPs are released into the water, the concentration of bioactive compounds is rapidly diluted via diffusion processes, and thus MNPs must be highly potent to have a long-reaching effect (Haefner 2003). Past studies have 
Fig. 8.1 (a) Cytarabine and (b) vidarabine (Mayer et al. 2010) (created with ChemDraw, v. 16.0.1.4)

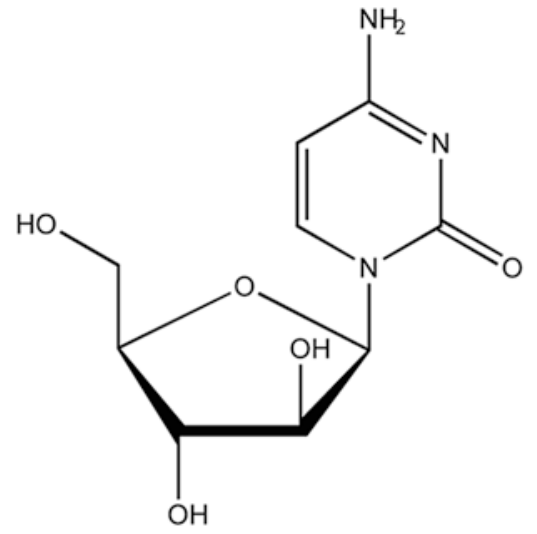

(a)

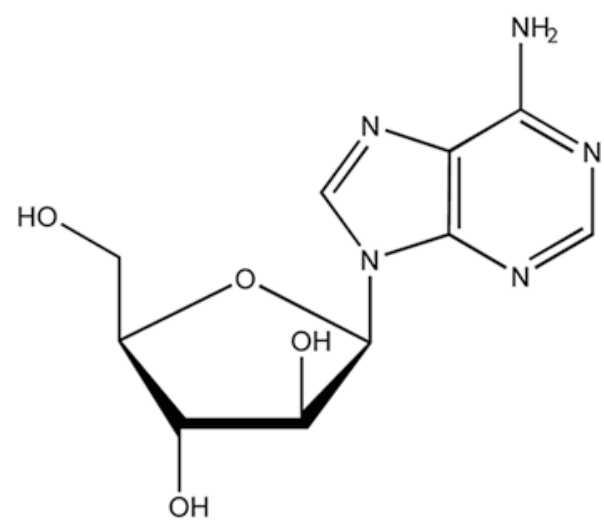

(b)

Table 8.1 Pipeline of marine pharmaceuticals until 2018 (according to http://marinepharmacology.midwestern.edu/clinical_pipeline.html, accessed 28 January 2018)

\begin{tabular}{l|l|l|l|l}
\hline Compound & Chemical class & Source org. & Therapeutic area & Status 2018 \\
\hline Cytarabine & Nucleoside & Sponge & Cancer & FDA-approved \\
\hline Vidarabine & Nucleoside & Sponge & Antiviral & FDA-approved \\
\hline Ziconotide & Peptide & Cone snail & Chronic pain & FDA-approved \\
\hline Trabectedin & Alkaloid & Tunicate & Cancer & FDA-approved \\
\hline Brentuximab vedotin & Antibody drug conjugate & Mollusk & Cancer & FDA-approved \\
\hline Eribulin mesylate & Macrolide & Sponge & Cancer & FDA-approved \\
\hline Omega-3-acid ethyl ester & Omega-3 fatty acid & Fish & Hypertriglyceridemia & FDA-approved \\
\hline Plinabulin & Diketopiperazine & Fungus & Cancer & Phase III \\
\hline Plitidepsin & Depsipeptide & Tunicate & Cancer & Phase III \\
\hline Bryostatin & Macrolide lactone & Bryozoan & Alzheimer's & Phase II \\
\hline Plocabulin & Polyketide & Sponge & Cancer & Phase II \\
\hline Marizomib & Beta-lactone-gamma-lactam & Bacterium & Cancer & Phase I \\
\hline
\end{tabular}

Chemical structures of all compounds listed in this table can be found in Figs. 8.1 and 8.2

shown that MNPs cover a wide variety of biological activities (Fig. 8.3), such as anticancer (Nastrucci et al. 2012), antibacterial (Hughes and Fenical 2010), antifungal, and antiviral effects (Mayer et al. 2013), making them a promising source for novel drugs. Figure 8.3 shows that different chemical classes of MNPs are showing equal proportions among a vast set of bioactivities, leading to the assumption that most chemical structures could either be developed or serve as scaffolds for the development of new drugs against various diseases (Hu et al. 2015).

Besides the investigation on marine invertebrates or algae, modern marine biotechnology expanded its interests onto the exploration of marine bacteria and fungi, since the latter have been recognized as renewable producers of SMs (i.e., under controlled laboratory conditions) in the drug discovery process (Waters et al. 2010). Both, bacteria and fungi associated with marine macroorganisms have shown to be potent producers of bioactive substances, in some cases with prominent activities against several pathogenic germs, viruses, and tumor cells (Imhoff et al. 2011 and references therein).

\subsubsection{Marine Bacteria: Widely Distributed Producers of Promising Natural Products}

Marine microorganisms managed to conquer every marine habitat ranging from shallow and deep marine waters, polar regions, and deep-sea hydrothermal vents to diverse coral reef ecosystems. Particularly, the surface of macroorganisms, such as algae, sponges, and corals, is a favorable ecological niche for marine microorganisms. In many cases, bacteria live in close association with higher organisms and form symbiotic or mutualistic relationships (Lee et al. 2009; Kazamia et al. 2012; Cooper and Smith 2015). There is growing evidence that the microbial community composition on marine macroorganisms is habitat and even species specific. Examples include differences in communities found on the surface of different algae (Lachnit et al. 2009), between different parts of the rhizoid and phylloid of the brown alga Saccharina latissima (Staufenberger et al. 2008), between different sponge species (Thomas et al. 2016; Moitinho-Silva et al. 2017), as well as between outer 


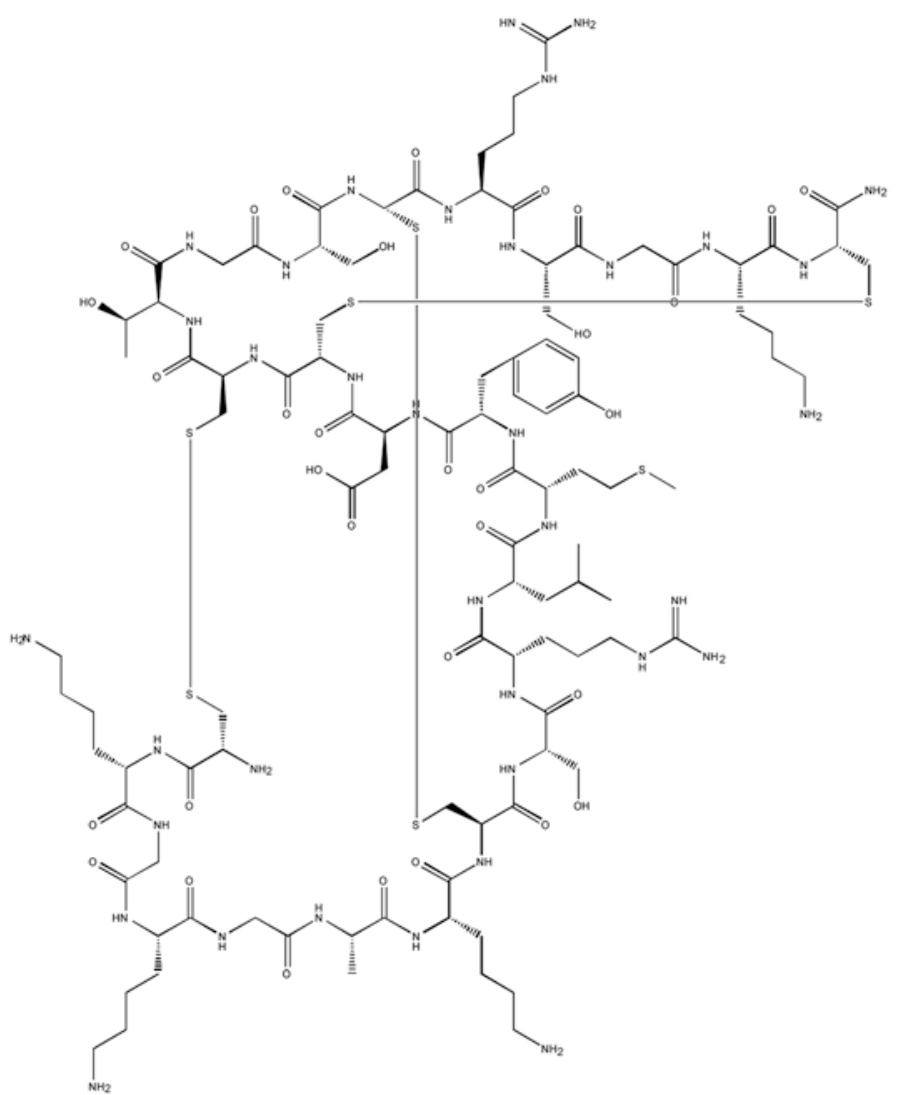

(a)

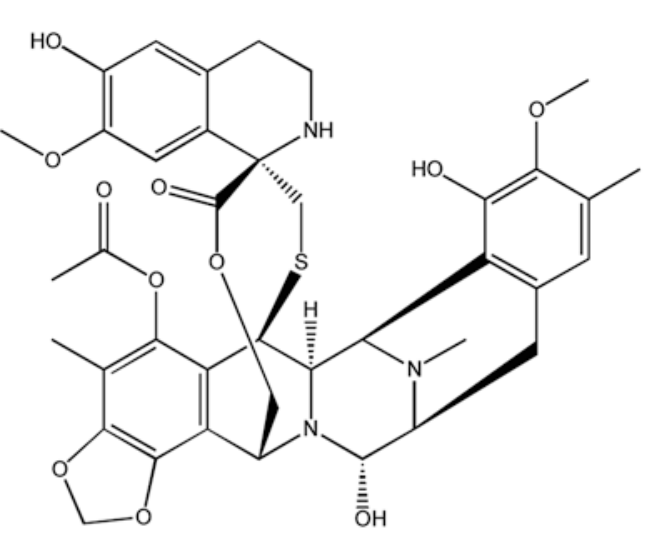

(b)<smiles>CC[C@H](C)[C@H]([C@H](CC(=O)N1CCC[C@]1([18OH])[C@H](OC)[C@@H](C)C(=O)N[C@@H](C)[C@H](O)c1ccccc1)OC)N(C)C(=O)[C@@H](NC(=O)[C@@H](NC)C(C)C)C(C)C</smiles>

(c)

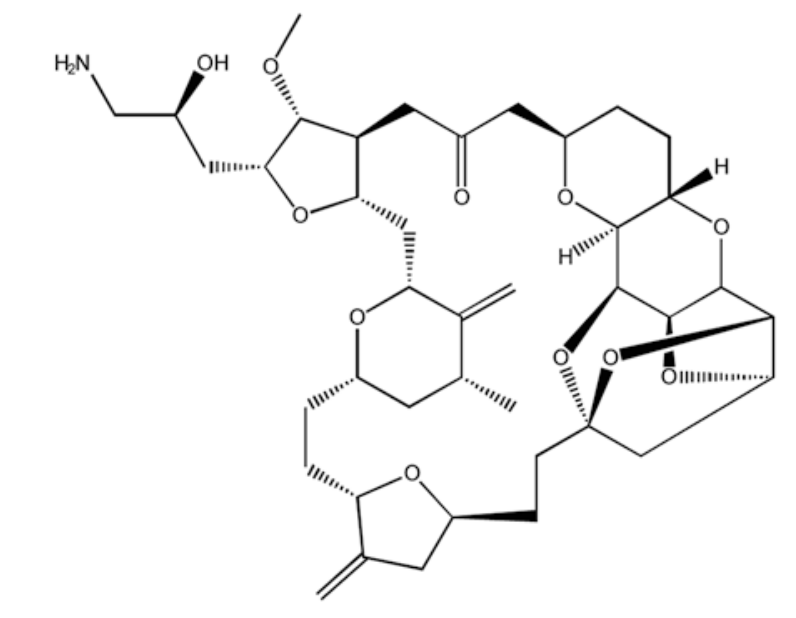

(d)

Fig. 8.2 Selected marine pharmaceuticals. (a) Ziconotide, (b) trabectedin, (c) monomethyl auristatin E, (d) eribulin, (e) omega-3 fatty acid, (f) plinabulin, (g) plitidepsin, (h) bryostatin, (i) plocabulin, and (j) mar- izomib (Mayer et al. 2010; modified from Lee et al. 2015; Pantazopoulou et al. 2018) (created with ChemDraw, v. 16.0.1.4) 
<smiles>CC(C)(C)c1[nH]cnc1/C=c1\[nH]c(=O)/c(=C/c2ccccc2)[nH]c1=O</smiles>

(f)

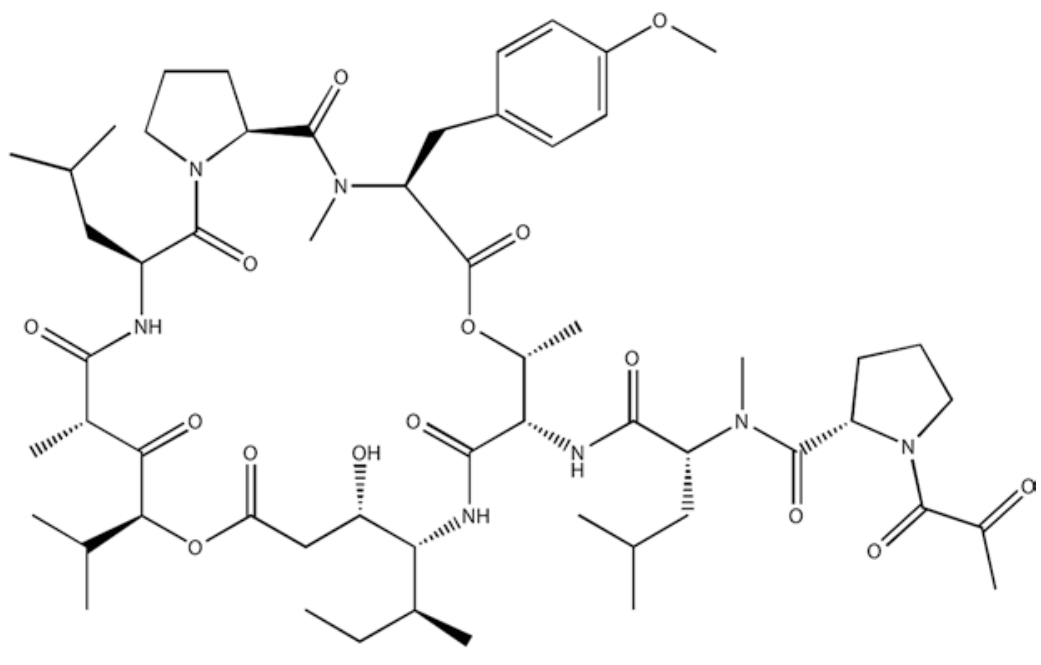

(g)

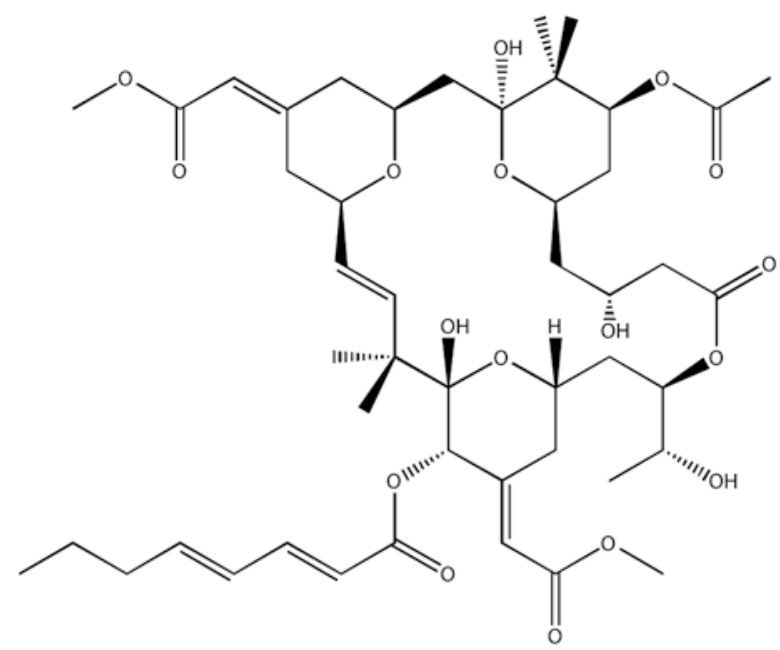

(h)

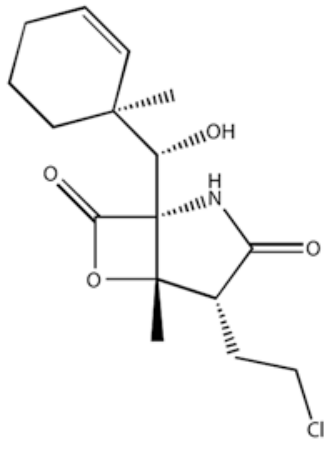

(j)<smiles>C/C=C/C[C@H](C/C=C/NC(=O)[C@@H](NC(=O)/C=C/C=C/C(C)=C/[C@@H](C)[C@H]1CC=C(OC)C(=O)O1)C(C)(C)C)OC(N)=O</smiles>

(i)

Fig. 8.2 (continued) 


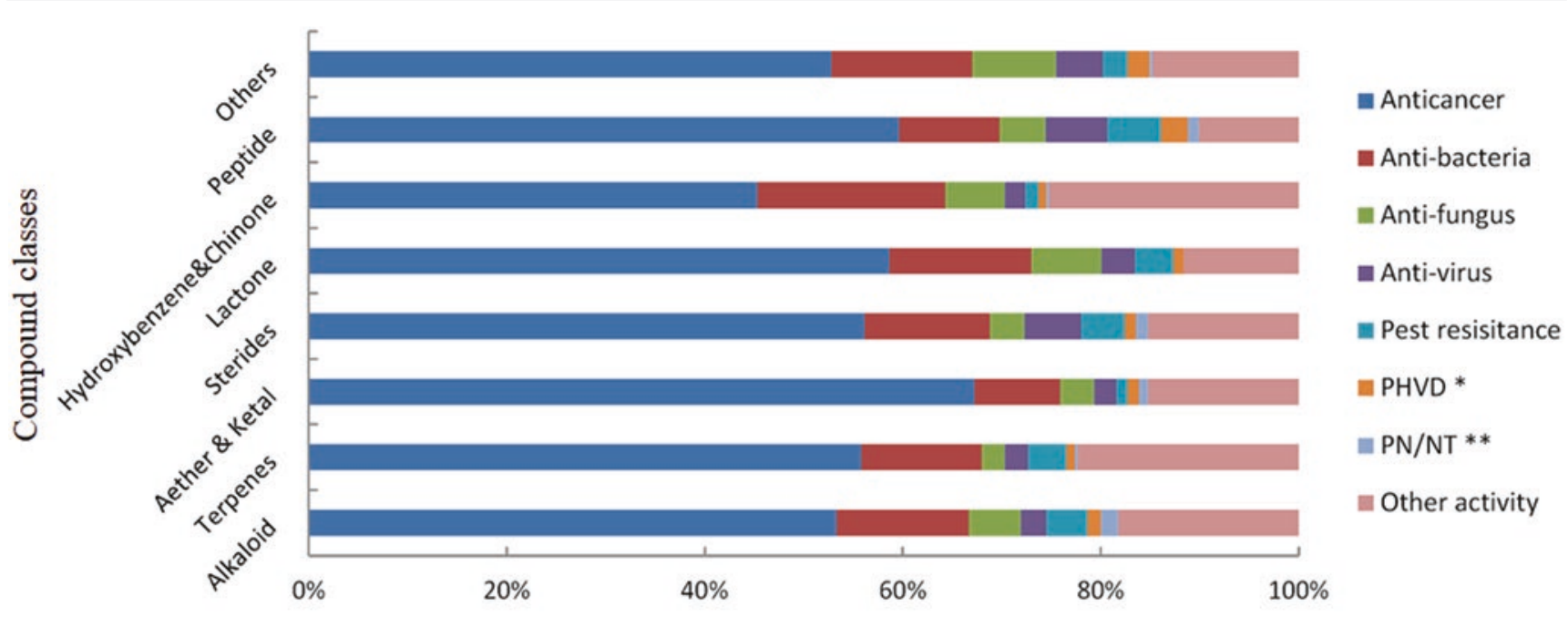

Proportions of biological activities

Fig. 8.3 Analysis of new marine-derived compounds from 1985 to 2012 according to chemical classes and biological activities ( $*$ PHVD, prevention of heart and vascular disease; $* * \mathrm{PN} / \mathrm{NT}$, protection of neurons/neurotoxicity) (modified from Hu et al. 2015)

and inner parts of the sponge Tethya aurantium (Thiel et al. 2007). However, the great microbial diversity of marine environments remains nearly untapped. Simon and Daniel (2011) estimated that less than $0.1 \%$, probably solely $0.01 \%$, of all microbes in the oceans have been characterized. Molecular analysis of marine metagenomes revealed a great number of phylogenetic lines of so far uncultured groups of bacteria and archaea (DeLong et al. 2006; Simon and Daniel 2009; Hug et al. 2016). Besides their important roles in shaping community structures and in mediating microbemicrobe as well as microbe-host interactions, marine bacteria are suggested to represent a treasure box of new compounds for biotechnology. This assumption is due to their high biodiversity and the gap of knowledge regarding their potential of NP biosynthesis (Imhoff et al. 2011). Yet, much evidence is given that marine bacteria produce new compounds useful for the discovery of novel pharmaceuticals (Rahman et al. 2010; Waters et al. 2010; Blunt et al. 2018). From 1997 to 2008, about 660 new marine bacterial NPs were identified. Most of them originated from the classes Actinobacteria (40\%) and Cyanobacteria (33\%), followed by Proteobacteria (12\%) and members of the Bacteroidetes and Firmicutes (5\%) (Williams 2009). In comparison, 179 novel NPs have been isolated from marine bacteria in 2016. This is only a moderate increase compared to the average number of new marine bacterial compounds in the last 3 years, but a significant increase from the average for the period of 2010 to 2012 (Blunt et al. 2018). Members of the Actinobacteria are a rich source of NPs and hold an unmatched capacity for the generation of new drugs (Bull et al. 2005; Bull and Stach 2007; Fenical and Jensen
2006). The first bioactive compound extracted from a marine actinomycete was the antibiotic SS-228Y, showing antibacterial activity to gram-positive bacteria. This biomolecule was proposed to be a peri-hydroxyquinone derivative produced by Streptomyces purpurogeneiscleroticus (Chainia purpurogena) collected from sea mud (Okazaki et al. 1975). Until today, the genus Streptomyces continues to be a prolific source of new and interesting chemistry; numerous compounds showed exciting bioactivities. For example, $S$. spinoverrucosus, isolated from a sand sample from the Bahamian tidal flats, produced the dibohemamines A-C, three new dimeric bohemamines. These compounds were shown to be formed via a nonenzymatic process with formaldehyde, which was also detectable in the growth media. Both metabolites dibohemamines B (Fig. 8.4a) and C exhibited potent activity against lung cancer cells, with $\mathrm{IC}_{50}$ values of $140 \mathrm{nM}$ and $145 \mathrm{nM}$, respectively (Fu et al. 2016). Another Streptomyces sp. isolated from a marine sediment sample collected off Oceanside, California, USA, produced the ansalactams A-D. The novel ansalactam derivatives (B-D) represent three new carbon skeletons and, therefore, display the plasticity within the ansamycin biosynthetic pathway. The latter three novel metabolites showed moderate antibacterial activity against MRSA (methicillin-resistant Staphylococcus aureus) (Wilson et al. 2011; Le et al. 2016). Apart from Streptomyces, species of the genera Salinispora and Marinispora were found to produce structurally novel bioactive compounds. A Salinispora tropica strain was isolated from a sediment sample, collected from a mangrove environment in Chub Cay, Bahamas. This strain produced several $\beta$-lactone-gamma-lactams, the salinospo- 
<smiles>CC(C)=CC(=O)NC1=C(CC2=C(NC(=O)C=C(C)C)N3[C@@H](C)[C@H](O)C[C@]3(C)C2=O)C(=O)[C@@]2(C)C[C@H](O)[C@H](C)N12</smiles>

(a)<smiles>CCCC[C@H](C)[C@H](CC(=O)CNC(=O)N[C@H](C(=O)N[C@@H](CC(C)C)C(=O)N[C@@H](C)C(=O)N[C@@H](Cc1ccccc1)C(=O)O)C(C)C)OC(=O)[C@H](C)CCCC</smiles>

(b)

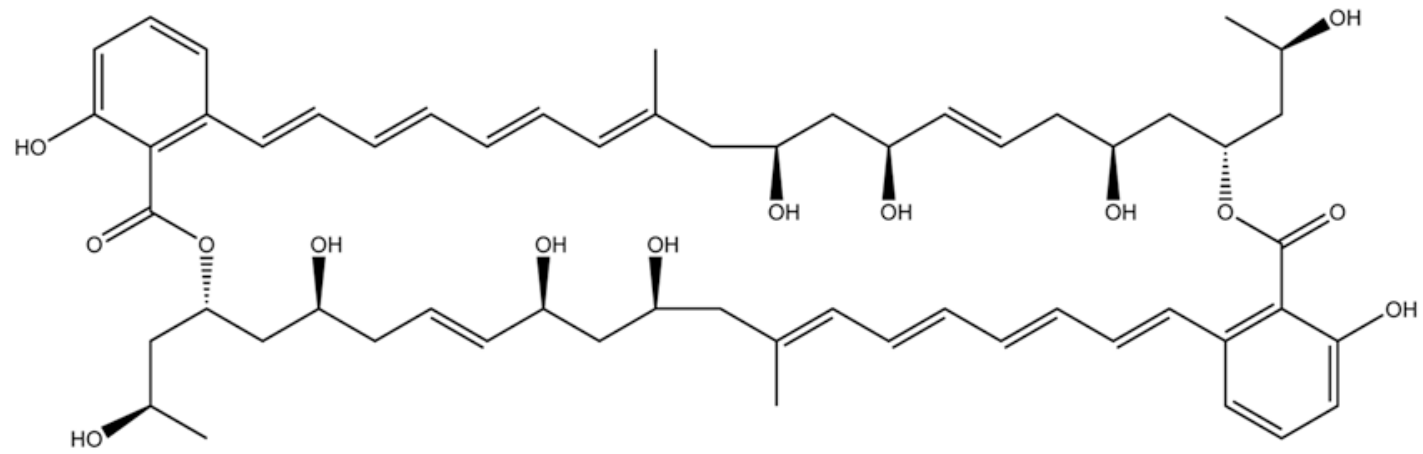

(c)<smiles>CC[C@H](C)[C@H]([C@H](CC(=O)N1CCC[C@H]1[C@H](OC)[C@@H](C)C(=O)N[C@H](Cc1ccccc1)c1nccs1)OC)N(C)C(=O)[C@@H](NC(=O)[C@@H](C(C)C)N(C)C)C(C)C</smiles>

(d)

Fig. 8.4 (a) Dibohemamine B (Fu et al. 2016), (b) arenamide B (Asolkar et al. 2009), (c) marinomycin A (Kwon et al. 2006), and (d) dolastatin 10 (Bai et al. 1990) (created with ChemDraw, v. 16.0.1.4)

ramides, which represent a new family of SMs (Feling et al. 2003; Williams et al. 2005). Specifically, salinosporamide A (marizomib; see Fig. 8.2j) displayed potent in vitro cytotoxicity against $\mathrm{HCT}-116$ human colon carcinoma with an $\mathrm{IC}_{50}$ value of only $11 \mathrm{ng} \mathrm{mL}{ }^{-1}$. Furthermore, this compound showed great potency against NCI-H226 non-small cell lung cancer, SK-MEL-28 melanoma, MDA-MB-435 breast cancer, and SF-539 CNS cancer, all with $\mathrm{LC}_{50}$ values less than $10 \mathrm{~nm}$ (Feling et al. 2003). As displayed in Table 8.1, marizomib has entered Phase I human clinical trials for the treatment of multiple myeloma (Martins et al. 2014; http:// marinepharmacology.midwestern.edu/clinical_pipeline. html, accessed 28 January 2018). Asolkar et al. (2009) found three new cyclohexadepsipeptides, namely, arenamides A-C, produced in the fermentation broth of a marine Salinispora arenicola, isolated from a sediment sample. Arenamide A and B (Fig. 8.4b) blocked TNF (tumor necrosis factor) induced activation in transfected 293/NFkB-Luc human embryonic kidney cells in a time- and dose-dependent manner with $\mathrm{IC}_{50}$ values of $3.7 \mu \mathrm{M}$ and $1.7 \mu \mathrm{M}$, respec- 
tively. The compounds also inhibited nitric oxide (NO) and prostaglandin $\mathrm{E}_{2}\left(\mathrm{PGE}_{2}\right)$ production with lipopolysaccharide (LPS)-induced RAW 264.7 macrophages. The authors suggest that the anti-inflammatory and chemoprevention characteristics of arenamides A and B are worth further investigation (Asolkar et al. 2009). Other examples for antibiotics with antitumor activity from marine Actinobacteria are the marinomycins. A Marinispora strain, isolated from an offshore sediment sample, produced the marinomycins A-D. The most promising compound within this novel class of polyketides is marinomycin A (Fig. 8.4c). It shows selectivity against several human melanoma cell lines with an $\mathrm{IC}_{50}$ value of $5 \mathrm{nM}$ for SK-MEL5 melanoma cells (Kwon et al. 2006). Besides Actinobacteria, members of marine Cyanobacteria are known to produce bioactive SMs too. For example, the peptide dolastatin 10 (Fig. 8.4d) was originally isolated from the sea hare Dolabella auricularia (Bai et al. 1990) but was then shown to be produced by the cyanobacterium Symploca sp. (Luesch et al. 2001). This natural product (NP) was used as a model for the synthetic development of soblidotin, which has entered Phase III clinical trials (Mayer et al. 2010). The cyclic depsipeptide largazole is produced by another marine Symploca sp. and inhibited the growth of highly invasive transformed human mammary epithelial cells in a dose-dependent manner $\left(\mathrm{GI}_{50} 7.7 \mathrm{nM}\right)$. It induced cytotoxicity at higher concentrations (117 nM) (Taori et al. 2008). All these examples show the potential of marine bacteria, specifically Actinobacteria and Cyanobacteria, to produce chemicals that cover a broad range of bioactivities and might be used for the generation of novel drug candidates.

\subsubsection{Marine Fungi: Bioprospecting the Future}

Compared to bacteria, the basic knowledge on marine fungi, hereinafter referring to obligate and facultative marine fungi, is still deficient in matters of diversity and ecological importance (Imhoff et al. 2011). The term "marine fungi" applies rather to an ecological background than to a distinct taxonomy or a physiological approach (Kohlmeyer and Kohlmeyer 1979). Within biology, marine fungi are mainly separated into two groups, namely, obligate marine fungi, which grow and sporulate exclusively in marine habitats, and facultative marine fungi, which originate from freshwater or terrestrial milieus and are capable to grow also in the marine environment (Kohlmeyer and Kohlmeyer 1979). By 1996, mycologists estimated the number of marine fungi to be approximately 1500 species, and by 2011, biodiversity estimations of marine fungi were placed to be more than 10,000 species (Jones 2011).
According to Overy et al. (2014), the examination of new substrata and geological locations will greatly increase the number of total species through the rapid discovery of new fungal species. However, marine fungal strains have been isolated from nearly every possible marine habitat until today, including soil and sediment (Wang et al. 2013; Simões et al. 2015), marine invertebrates (e.g., sponges and corals) (Wiese et al. 2011; Amend et al. 2012), marine plants (e.g., algae) (Loque et al. 2010), and marine vertebrates (fishes) (Rateb and Ebel 2011). Algae have been used primarily as a source for bioprospecting fungal diversity, closely followed by sponges and mangrove habitats (Fig. 8.5). Efforts to isolate these symbionts within new and sometimes extreme habitats are still being made. A study on the fungal community by a culture-dependent approach revealed that several Antarctic sponges of the phylum Ascomycota were a rich source of associated fungi and novel SMs, with some of them showing antimicrobial, antitumoral, and antioxidant potential (Henríquez et al. 2014). Furthermore, due to the development of deep-sea instrumentation and new techniques used for sampling, the deep-sea habitat emerged as a new and highly promising source for marine fungal biodiversity, and thus an excessive number of novel fungal specimen have been retrieved (Wang et al. 2015). For example, Burgaud et al. (2009) investigated the biodiversity of culturable filamentous fungi and uncovered the presence of both Ascomycota and Basidiomycota associated with different deep-sea samples, including sediment, mussels, shrimps, and smoker rock scrapings. However, as an outcome of the recent bioprospecting efforts, biotechnological interests have mostly turned to marine microorganisms and notably fungi as a likely source for MNPs (Fig. 8.6) (Bhadury et al. 2006).

By 1992, only 15 marine fungal metabolites had been described (Fenical and Jensen 1993), and this number rose to 270 until 2002 (Bugni and Ireland 2004). Within the period from 2006 until mid-2010, Rateb and Ebel (2011) summarized 690 NPs from fungi isolated from marine habitats. With Penicillium spp. and Aspergillus spp. being the most potent producers, their study revealed that nearly $50 \%$ of the compounds are polyketides and their prenylated forms, whereas alkaloids, terpenoids, and peptides contributed 15\%-20\% (Rateb and Ebel 2011). A famous example of a NP from a marine fungus is the diketopiperazine halimide (Fig. 8.6a), an aromatic alkaloid of a marine Aspergillus sp. isolated from the green alga Halimeda copiosa (Fenical 1999). Its synthetic analog, plinabulin (Fig. 8.2f), is showing antitumor activity by causing tubulin depolymerization, thereby leading to the disruption of tumor cells followed by necrosis of the tumor itself (Gullo et al. 2006). Up to today, plinabulin is the only marine fungal synthetic analog that has entered clinical trials and successfully passed the first and second phase (Gomes et al. 2015; www.beyondspringpharma.com/en/pipeline/, accessed 28 


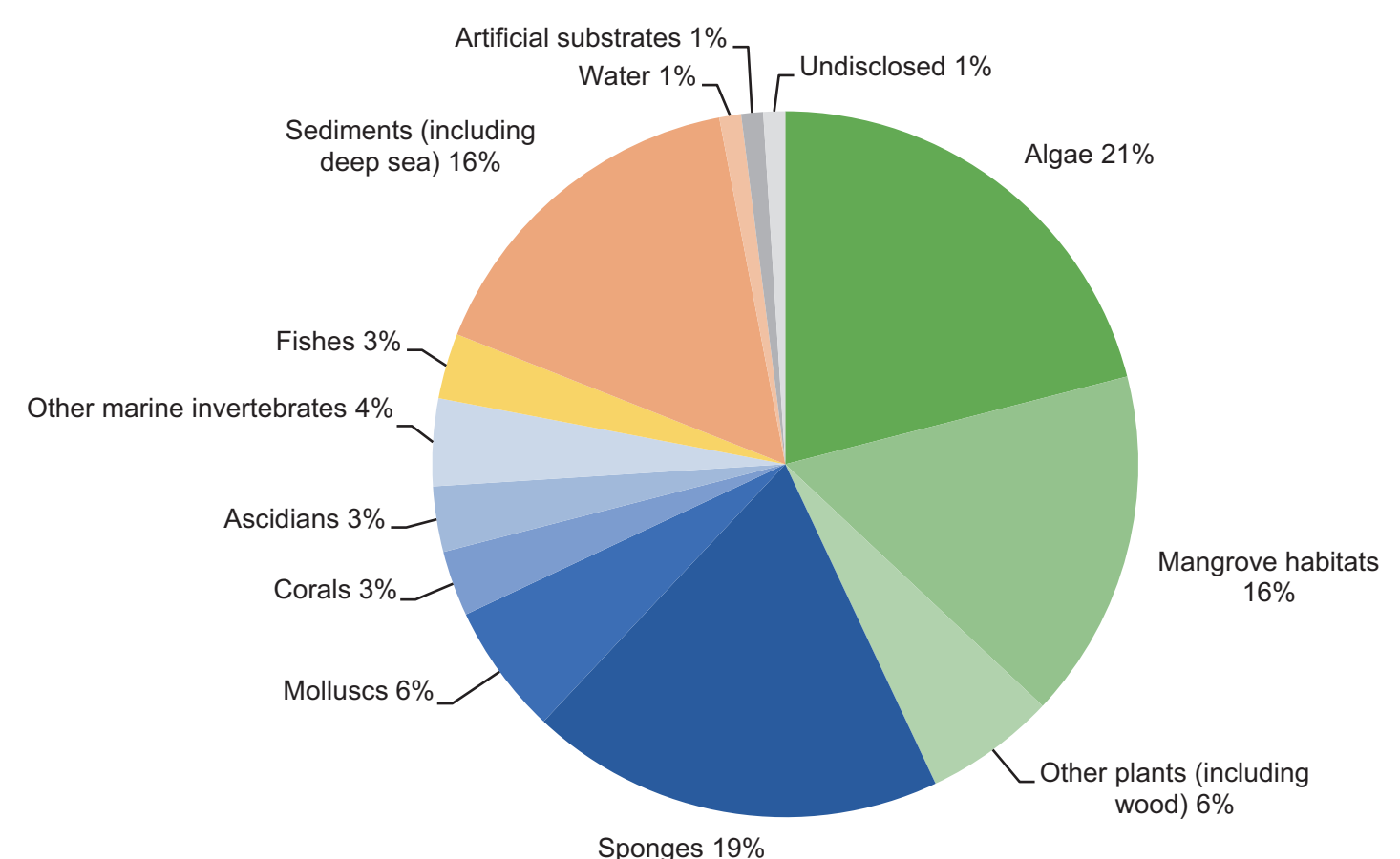

Fig. 8.5 Sources of marine fungi-producing MNPs until 2010 (reproduced from Rateb and Ebel 2011)

Fig. 8.6 (a) Halimide (Fenical 1999), (b) chaetoxanthone B (Gademann and Kobylinska 2009), and (c) pestalone (Cueto et al. 2001) (created with ChemDraw, v. 16.0.1.4)<smiles>C=CC(C)(C)c1[nH]cnc1/C=C1\NC(=O)[C@@H](Cc2ccccc2)NC1=O</smiles>

(a)<smiles>COc1cccc2oc3cc4c(c(O)c3c(=O)c12)[C@@H]1CCC[C@](C)(O4)O1</smiles>

(b)<smiles>COc1c(Cl)c(C)c(Cl)c(O)c1C(=O)c1c(C=O)c(O)cc(O)c1CC=C(C)C</smiles>

(c)

January 2018). A further example was given by Pontius et al. (2008), who isolated chaetoxanthone B (Fig. 8.6b) from a marine Chaetomium sp., showing selective antimalarial activity against Plasmodium falciparum $\left(\mathrm{IC}_{50}=0.5 \mu \mathrm{g} \mathrm{mL}^{-1}\right)$ and moderate activity against Trypanosoma cruzi $\left(\mathrm{IC}_{50}=1.5 \mu \mathrm{g} \mathrm{mL}^{-1}\right)$ without or with only minimal cytotoxicity toward cultured eukaryotic cells. Another promising marine NP is the chlorinated benzophenone pestalone (Fig. 8.6c), 
which has been isolated from the fungus Pestalotia sp., which is associated with the brown alga Rosenvingea sp. and was collected near the Bahamas Islands. Although pestalone was only produced when Pestalotia sp. was cocultured with a marine bacterium, this compound showed potent activities against methicillin-resistant Staphylococcus aureus and vancomycin-resistant Enterococcus faecium strains, indicated by minimum inhibitory concentrations (MIC) of $37 \mathrm{ng} \mathrm{mL}^{-1}$ and

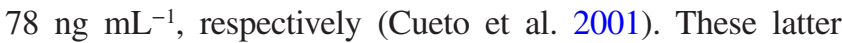
examples encourage the ongoing research activities on novel marine fungal species for the future development of new drugs. Considering that $38 \%$ of the approximately 22,000 bioactive microbial metabolites are of fungal origin, and that only about $5 \%$ of the world's fungal taxa have been described, fungi exhibit a tremendous potential for the discovery of novel bioactive SMs (Schulz et al. 2008). To avoid the rediscovery of already known compounds, specialized and effective dereplication strategies need to be constantly employed (Martins et al. 2014). For this purpose, the most common techniques are a combination of chemical compound separation hyphenated to various spectroscopic or mass-selective detection methods such as high-performance liquid chromatography (HPLC) coupled to either a diode array detector (HPLC-DAD) or a mass spectrometer (HPLC-MS) (Wolfender et al. 2010). Besides nuclear magnetic resonance (NMR) spectroscopy, HPLC-MS is another predominant analytical technique for the fast detection and identification of SMs and other small molecules. A major advantage of MS over NMR is that MS-based methods are far more sensitive, making it the method of choice when it comes to first-pass compound detection and identification in high-throughput screening applications (Carrano and Marinelli 2015). Moreover, it provides accurate mass even within the nanogram range, which can be used as a search criterion or query in nearly all NP databases (Nielsen et al. 2011). On the contrary, NMR is by far the most efficient method to unambiguously elucidate complex structures of small molecules (Hubert et al. 2017). One of its advantages compared to MS strategies is that it serves as a quantitative analysis without the need of a suitable reference material (Kurita and Linington 2015). The ${ }^{1} \mathrm{H}-\mathrm{NMR}$ is also useful for evaluating the purity of a given sample. For example, impurities such as lipids are somewhat invisible in HPLC-DAD-MS techniques due to their low UV absorption, hydrophobicity, and contumaciousness to ionization, but they can easily be seen in ${ }^{1} \mathrm{H}-\mathrm{NMR}$ (Carrano and Marinelli 2015). After the collection of UV/VIS absorption spectra, molecular mass, and further structure data, the gained information needs to be compared with database entries. Over the decades, many different databases covering a wide range of compounds have been established (Mohamed et al. 2016; Guijas et al. 2018), including general compound libraries like SciFinder (www. scifinder.cas.org, accessed 28 January 2018), NP libraries such as
AntiBase (www.wiley-vch.de/stmdata/antibase.php, accessed 28 January 2018) or Dictionary of Natural Products (dnp. chemnetbase.com, accessed 28 January 2018), and even some free-to-use databases like ChemSpider (www.chemspider. com, accessed 28 January 2018), PubChem (pubchem.ncbi. nlm.nih.gov, accessed 28 January 2018), or Metlin (metlin. scripps.edu, accessed 28 January 2018). In addition to this widespread dereplication approach, fragmentation-based MS methods, also referred to as MS/MS or tandem mass spectrometry, in combination with molecular networking are receiving increasing attention for the identification of unknown compounds. For example, the Global Natural Products Social (GNPS) molecular networking website (http://gnps.ucsd.edu) is an open-access knowledge base that aims to let NP chemists work together and share their raw, processed, or identified MS/MS spectrometry data. We believe that crowdsourced curation of freely available reference MS libraries as well as a fast-growing database of MS/MS spectra will rapidly accelerate the annotation and thus the search of prior unknown compounds (Wang et al. 2016; Kind et al. 2017; Quinn et al. 2017).

\subsection{Marine Chemical Ecology: Predator- Prey Interactions and Competition}

During the last decades, marine chemical ecology has evolved from a young science with mostly NP chemists finding new SMs with potentially obscure ecological functions into a matured research field that simultaneously combines chemical and biological aspects. Besides their side effect of exhibiting utilizable bioactivities for humankind, chemical cues possess major influences on every organizational level in the marine system. Several reviews highlight the importance of chemical communication between benthic and pelagic organisms for a better understanding of marine ecosystem functioning (i.e., Hay 1996, 2009; Sieg et al. 2011; Paul et al. 2011; Puglisi et al. 2014). However, most marine organisms are rather organized in highly biodiverse and productive communities occurring in ocean fringes, such as coral reefs or offshore zones, than being distributed all over the ocean (Simmons et al. 2005; Das et al. 2006). Many of these biological communities are characterized by the presence of extremely harsh conditions in matters of UV radiation (light stress at water surface), temperature, pressure, and salinity. In addition to these environmental stressors, sessile benthic organisms are often in strong competition for available resources such as space (to settle and grow) and nutrients. As a result, survival and reproduction between the competing organisms can strongly depend on their ability to produce bioactive SMs (de Carvalho and Fernandes 2010). These bioactive substances can perform various tasks for their producers and associated organisms; for instance, SMs work as a chemical defense against predators 
(Pohnert 2004; Kubicek et al. 2011; Rasher et al. 2013; Rohde et al. 2015; Helber et al. 2017), function as attractants toward consumers (Sakata 1989), have antimicrobial effects against pathogenic microbes (Goecke et al. 2010; Puglisi et al. 2014; Helber et al. 2018), guide the opposing sex by letting individuals find and evaluate potential mating partners through chemical cues (Lonsdale et al. 1998; Li et al. 2002), or act as settlement cues for invertebrate larvae to initiate the transformation into a sessile, juvenile form (Morse et al. 1988; Heyward and Negri 1999; Negri et al. 2001; Kitamura et al. 2009; Tebben et al. 2011, 2015; Sneed et al. 2014). For example, different classes of macroalgae defend themselves chemically against herbivores and produce SMs with antimicrobial and antifouling activity (Schupp and Paul 1994; Paul et al. 2014; Schwartz et al. 2016). Specifically, brown algae of the family Dictyotaceae produce several classes of diterpenes that defend their producers against herbivores but have also shown activity against other competitors. It has been reported that natural concentrations of a diterpene of the dolastane class (Fig. 8.7a), originally isolated from the brown alga Canistrocarpus cervicornis, reduce feeding activity by the sea urchin Lytechinus variegatus (Bianco et al. 2010). In a study of Craft et al. (2013), lipophilic extracts of nine subtropical algae were offered to four subtropical and three cold-temperate sea urchins at two concentrations. While the extracts of the subtropical marine algae Caulerpa sertularioides, Dictyota pulchella, and D. ciliolate deterred all urchins, the other macroalgae extracts from the cold-adapted areas led to different feeding resistance patterns. Apart from anti-herbivore activity, many macroalgae are known for their antimicrobial and antifouling activity (Goecke et al. 2010, 2012; Pérez et al. 2016; Schwartz et al. 2017). A review by Harder et al. (2012) highlights the crucial role of halogenated furanones (Fig. 8.7b, c) within the red alga Delisea pulchra and how these compounds interact with the associated bacteria. The halogenated furanones deter fouling by bacterial pathogens and epiphytic bacteria through interference with bacterial quorum sensing. By imitating quorum sensing-mediating acyl homoserine lactones to block the same receptor sites, halogenated furanones can manipulate bacterial colonization and biofilm formation as well as bleaching and diseases caused by pathogenic bacteria. Besides macroalgae, sponges and their associated microbes are another prolific source of potentially novel NPs with promising bioactivities. Although the ecological role of sponge crude extracts has been evaluated for numerous sponge species, assignment of activities to specific NPs is lacking behind. Investigated bioactivities included antipredatory, antifouling, antimicrobial, and allelopathic functions (Rohde et al. 2015; Helber et al. 2017, 2018). Several studies are providing evidence that sponges are chemically defended from predation and pathogens by compounds that either the host or other associated microorganisms had produced (Pawlik 2011;
Hentschel et al. 2012). The Mediterranean sponge Axinella verrucosa, collected from the Gulf of Naples, Italy, produces hymenidin (Fig. 8.7d) and debromo-carteramine A (Fig. 8.7e), two bromopyrroles that are also known from other sponges. The $n$-butanol part of the A. verrucosa extract, containing the two bromopyrroles as well as the pure hymenidin, showed activity against microbial fouling and deterred feeding by the generalist shrimp Palaemon elegans at naturally occurring concentrations (Haber et al. 2011).

Several studies have shown that sponges of the same genus and even of the same species can produce different SMs. This circumstance raises the question to what extend SMs have evolutionary advantages for the survival of sponges. A study of Noyer et al. (2011) showed that several populations of Spongia lamella, collected in the Mediterranean Sea, spanning a region of $1200 \mathrm{~km}$, had an extremely high intraspecific chemical diversity. While nitenin (Fig. 8.7f) and ergosteryl myristate (Fig. 8.7g) were the major metabolites, the number of compounds as well as their concentrations changed among populations collected from different geographic locations. The authors suggested that these variations may have been due to both genetic and environmental factors. A further study on S. lamella revealed that the populations from the five regions (Portugal, Gibraltar, Baleares, Catalonia, and South France) significantly differed within their genetic and chemical diversity as well as their associated bacteria (Noyer and Becerro 2012). Similarly, Rohde et al. (2012) found different metabolites and compound concentrations in the tropical sponge Stylissa massa across different ocean basins and within sites. Compound concentration varied among individuals, and no correlation between compound concentrations and factors such as depth, UV, predation, and microbial growth could be identified. The authors concluded that concentrations could be affected by other selective pressures such as water temperature, water quality, light conditions, and food availability or that the observed variations reflected population-specific constitutive defenses. Another activity that has received increased attention recently are allelopathic actions of sponges by which they can outcompete scleractinian corals. Sponges have become an increasingly dominant species in the Caribbean reefs (Maliao et al. 2008; Colvard and Edmunds 2011; Perry et al. 2013; Villamizar et al. 2013; Loh and Pawlik 2014) and to a lesser extend in the Indo-Pacific (Bell and Smith 2004; Bell et al. 2013; Helber et al. 2017) as coral reef systems are permanently threatened by multiple decades of loss of reefbuilding corals due to climate change, disease, and pollution. In contrast to the calcium carbonate skeleton of corals, sponge skeletons are made of silica or protein, making them less sensitive to ocean acidification and temperature shifts (Pawlik 2011; Bell et al. 2013). Apart from being environmentally more robust, sponges can also outcompete corals 


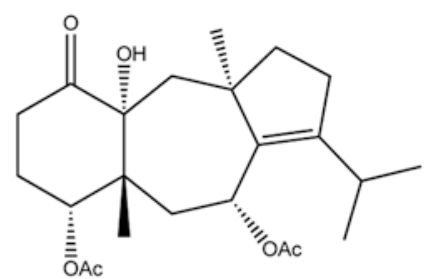

(a)<smiles>[R]C([R])=C1OC(=O)C(C([R])CCC)=C1Br</smiles>

(c)<smiles>[R]C(CCC)C1=C(Br)C([R])([R])OC1=O</smiles>

(b)<smiles>Nc1ncc(/C=C/CNC(=O)c2cc(Br)c[nH]2)[nH]1</smiles>

(d)

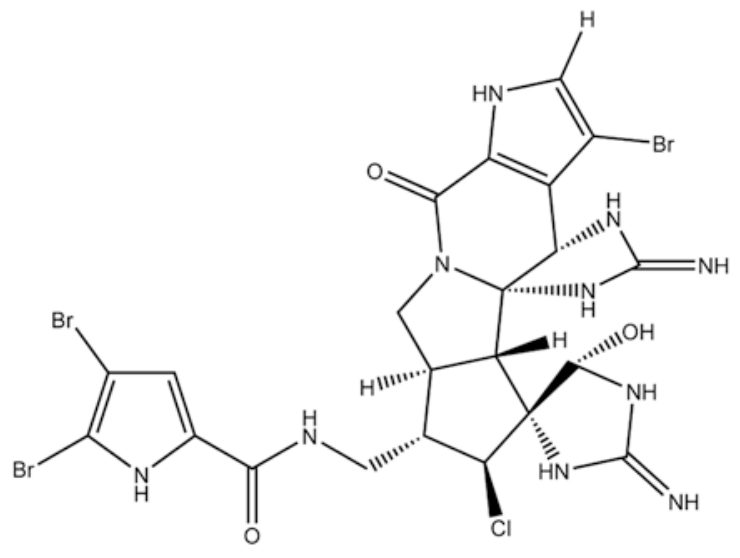

(e)<smiles>C/C(=C\[C@H]1CC(=CCCc2ccoc2)C(=O)O1)CCCc1ccoc1</smiles>

(f)

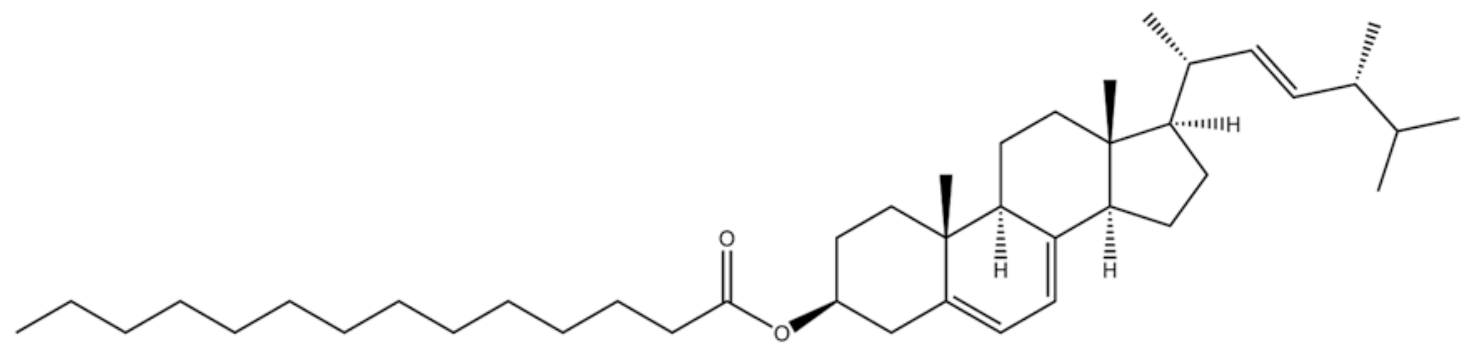

(g)

Fig. 8.7 (a) A diterpene (Bianco et al. 2010), (b, c) two halogenated furanones (Harder et al. 2012), (d) hymenidin, (e) debromo-carteramine A (Haber et al. 2011), (f) nintenin, and (g) ergosteryl myristate (Noyer et al. 2011) (created with ChemDraw, v. 16.0.1.4) 
by chemically affecting the coral symbionts through allelopathy. Crude extracts of several sponges collected from the Caribbean reefs were embedded in stable gels at natural concentrations and caused a decrease in the photosynthetic potential of the symbiotic zooxanthellae from the brain coral Diploria labyrinthiformis. Interestingly, sponge extracts influenced the symbiotic zooxanthellae in two ways: impairing photosynthesis with bleaching and with only little or no bleaching at all (Pawlik and Steindler 2007). Similarly, organic extracts of three sponges collected from Zanzibar reduced the photosynthetic performance of symbionts in the scleractinian coral Porites sp. (Helber et al. 2018). In addition to allelopathy on adults, it has been reported that spongederived SMs can negatively affect invertebrate larvae settlement too (Thompson 1985; Thompson et al. 1985; Bingham and Young 1991; Hellio et al. 2005). Since there have been several reviews in recent years on the role of SMs in chemical ecology and specifically chemical defense (Paul et al. 2011; Pawlik 2011; Rohde and Schupp 2018), we decided to focus in the remaining part of this review on the role of SMs during the settlement process of invertebrates (a role which has to this point received less attention).

\subsubsection{Marine Invertebrate Larvae Settlement: Role of Secondary Metabolites}

Many benthic marine invertebrates such as corals, sponges, mussels, or worms have a planktonic phase followed by a metamorphic event that transforms them into a less mobile or immobile, sessile benthic form. Since the process of attachment and metamorphosis for most organisms is generally irreversible (Thorson 1950), the choice of a suitable location for settlement is crucial for invertebrate larvae regarding survival, population dynamics, and community functioning. In the past, two models have been developed to explain the settlement of marine invertebrate larvae: (1) the stochastic model postulated that the settlement process happens randomly as soon as suitable substrate becomes available and that postmetamorphic events arrange the final distribution of juveniles, and (2) the deterministic model suggested that specific environmental factors determine the attachment and metamorphosis of larvae as well as their final distribution. Nowadays, there is great evidence that the settlement process of invertebrate larvae is mainly biologically and chemically driven, although environmental parameters may also influence settlement behavior (Sebens 1983; Morse et al. 1988; Mundy and Babcock 1998; Lau and Qian 2001; Lau et al. 2005; Tebben et al. 2015; Da-Anoy et al. 2017). Chemical settlement cues are produced by a variety of marine organisms. Some invertebrate larvae like to settle among individuals of their own species, while others preferably settle upon other species, resulting in gregarious or associative settle- ment, respectively. Gregarious settlement has been reported for many phyla including polychaete worms and barnacles (Hadfield and Paul 2001). Live adults of the polychaete Hydroides dianthus were capable of eliciting gregarious settlement responses in conspecific larvae. Interestingly, settlement in response to live adults with or without their tubes as well as to their amputated tentacular crowns was significantly greater compared to dead worms, empty tubes, or biofilm covered slides. Moreover, after extraction of aggregations of adult worms with organic solvents, the inductive capacity of the remaining tissue was lost, and the activity went into both the nonpolar and polar fractions of the crude extract (Toonen and Pawlik 1996). Gregarious settlement of invertebrate larvae has long been assumed to be induced by contact with adult conspecifics (Crisp and Meadows 1962, 1963; Clare and Matsumura 2000). It has been shown that a glycoprotein with high molecular weight isolated from the adult barnacle Amphibalanus amphitrite, termed the settlementinducing protein complex (SIPC), induced settlement of cypris larvae (Matsumura et al. 1998; Dreanno et al. 2006). Nevertheless, there are reports showing that waterborne cues are able to induce gregarious settlement as well. Endo et al. (2009) isolated a previously undescribed $\sim 32-\mathrm{kDa}$ watersoluble protein from extracts of $A$. amphitrite adults that is distinct from SIPC and induced settlement of cyprids. This protein quickly induced searching behavior of conspecific larvae and was therefore proposed to act as a waterborne settlement pheromone. Elbourne and Clare (2010) provided evidence that settlement of $A$. amphitrite larvae can be induced by an unknown waterborne cue produced by conspecific adults both in the field and in the laboratory. These authors suggest that the ecological role of water-soluble settlement cues might be to facilitate the transition of invertebrate larvae out of the plankton by stimulating searching behavior, rather than attachment and metamorphosis caused by surface-bound settlement cues. Besides gregarious settlement, associative settlement is another form and can be divided into several subcategories, including herbivorous/ predatory relationships, parasitic relationships, and nonparasitic or symbiotic relationships. There are already some fully and partially characterized chemical compounds described; however, their ecological relevance often remains obscure (Pawlik 1992; Hadfield and Paul 2001). The quinol jacaranone (Fig. 8.8a), isolated from the red alga Delesseria sanguinea, induces larval settlement in Pecten maximus (Yvin et al. 1985), although this scallop has previously not been described to settle on this kind of red alga with any specificity (Chevolot et al. 1991; Nicolas et al. 1998). Another example is given by Williamson et al. (2000), who at first isolated a water-soluble complex of the sugar floridoside and isethionic acid in a 1:1 ratio from Delesseria pulchra. This floridoside-isethionic acid complex induced metamorphosis and reversible settlement in the sea urchin Holopneustes pur- 
<smiles>COC(=O)CC1(O)C=CC(=O)C=C1</smiles>

(a)<smiles>Brc1[nH]c(Br)c(Br)c1Br</smiles>

(c)<smiles>NCCc1c[nH]cn1</smiles>

(b)<smiles>COC1=C(Br)[C@@H](O)[C@@]2(C=C1Br)CC(C(=O)NC[C@@H](O)c1cc(Br)c(OCCCNC(=O)C3=NO[C@@]4(C=C(Br)C(OC)=C(Br)[C@H]4O)C3)c(Br)c1)=NO2</smiles>

(d)

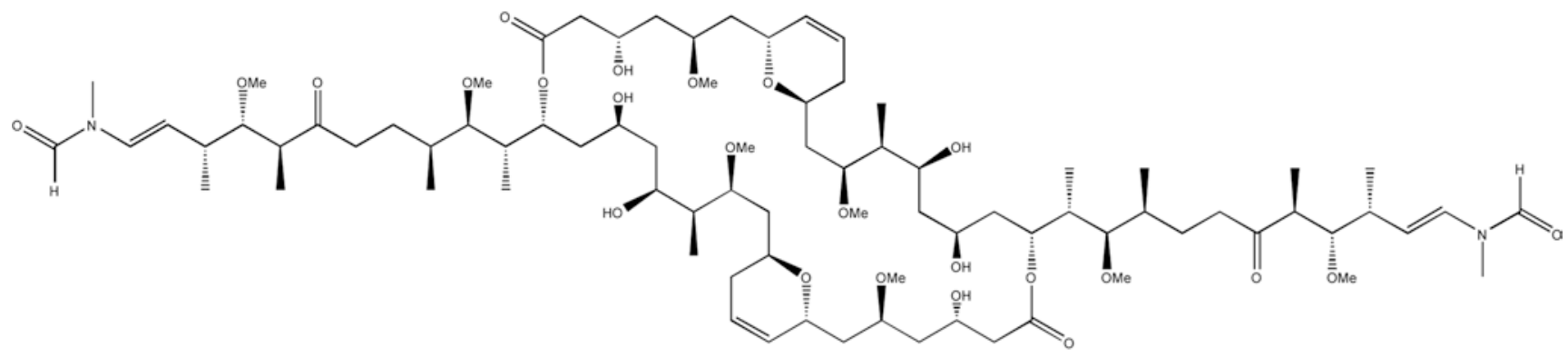

(e)

Fig. 8.8 (a) Jacaranone (Yvin et al. 1985), (b) histamine (Williamson et al. 2000), (c) tetrabromopyrrole (Tebben et al. 2011), (d) 11-deoxyfistularin-3 (Kitamura et al. 2007), and (e) luminaolide (Maru et al. 2013) (created with ChemDraw, v. 16.0.1.4)

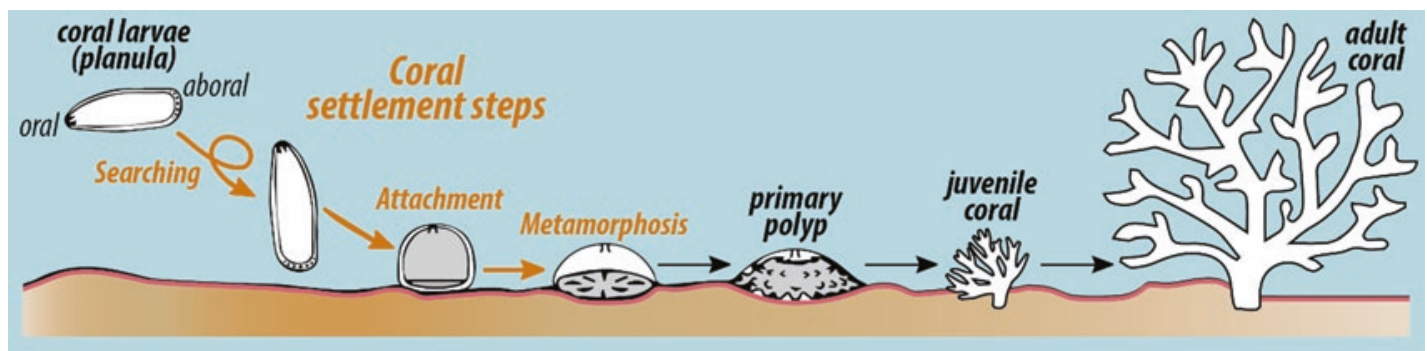

Fig. 8.9 Settlement and early life stages of scleractinian corals. This figure highlights on the first steps of a coral larvae (searching, attachment, and metamorphosis) toward an adult coral

purascens. In a following study, Swanson et al. (2004) were unable to reproduce these results. Instead, they found that histamine (Fig. 8.8b), isolated from the polar extract of $D$. pulchra, induced rapid settlement in $80-100 \%$ of the larvae of $H$. purpurascens. As larval settlement can be distinguished between searching, attachment, and metamorphosis (see Fig. 8.9; exemplarily shown for coral larvae), it is questionable if a single cue can induce the settlement chain or if sev- 
eral different cues are sequentially involved. Several studies on the settlement of different marine invertebrate larvae have indeed proven that single molecules can induce the whole chain of settlement, although only a few catalysts have been fully chemically characterized (Yvin et al. 1985; Pawlik 1986; Pawlik et al. 1991; Tsukamoto et al. 1999; Swanson et al. 2004; Dreanno et al. 2006). Only three of the latter studies have supported the ecological role of their investigated signaling molecules by also applying ecologically realistic concentrations (Pawlik 1986; Swanson et al. 2004; Dreanno et al. 2006). Meanwhile, tetrabromopyrrole (Fig. 8.8c), a tetrabrominated pyrrole, has been isolated from a marine Pseudoalteromonas sp. associated to the crustose coralline algae (CCA) Neogoniolithon fosliei, showing settlement activity in larvae of the branching stony coral Acropora millepora. Interestingly, coral larvae directly underwent metamorphosis by developing into primary polyps within a few hours, but only a small amount of them conducted attachment to the substratum, a process normally administered before metamorphosis is initiated (Tebben et al. 2011). Somewhat the same applies to 11-deoxyfistularin-3 (Fig. 8.8d), a bromotyrosine derivative that has been isolated from an unnamed CCA overgrowing coral rubble collected in Okinawa, Japan. This secondary metabolite induced solely metamorphosis in larvae of the scleractinian coral Pseudosiderastrea tayamai. Metamorphosis activity was further enhanced by the addition of fucoxanthinol and fucoxanthin, which are two carotenoids that had been isolated from the same CCA as well (Kitamura et al. 2007). Given the high number of studies on marine invertebrate settlement, it is very likely that additional examples of larvae relying on waterborne or surfacebound cues for gregarious and associative settlement will be described in the future. Furthermore, we are convinced that future studies will not only focus on the discovery of novel chemical settlement cues but also provide more information on their role in the mechanism of the settlement cascade and on their broader ecological functions.

\subsubsection{Coral Larvae Settlement: Search for Novel Settlement Cues}

Coral reefs are among the world's most diverse ecosystems and serve as nursery grounds and feeding areas for many reef-dependent animal species. Due to their relative complex physical structure, coral reefs shape the otherwise flat sea floor into a three-dimensional structure that provides a combination of food and shelter for a high biomass of commercially important fish species and other associated fauna (Moberg and Folke 1999). Besides their manifold ecosystem services, coral reefs affect humankind by having a major impact on economy and politics. Coral reefs provide food via commercial fisheries (Pauly et al. 2002), protect coastlines from destruction by waves (Barbier et al. 2011), and generate income from food and tourism (Bellwood et al. 2004). Unfortunately, corals reefs are also highly threatened ecosystems with some local and global factors being responsible. Local factors include declining water quality, destructive fishing, and increased pollution from urban areas. Global factors are global warming and ocean acidification, due to a dramatic rise of carbon dioxide levels in the atmosphere over the past century (Hoegh-Guldberg et al. 2007). Stony "reefbuilding" corals (Scleractinia) live in symbiosis with microalgae named zooxanthellae, which provide their coral hosts with up to $90 \%$ of their energy through photosynthesis (Stanley 2006). This relationship can be disrupted by environmental stressors such as long-lasting temperature increases together with intense periods of high sun irradiance. As a response to the latter stressor, corals expel their algae and thus lose their photosynthetic pigments at the same time, leading to the phenomenon of skeletal-looking bright white corals, a process better known as "coral bleaching" (Ainsworth et al. 2016; Heron et al. 2016). Such bleaching events have been increasing in the last two decades, thereby affecting reefs on a global scale. The severity of events caused coral mortalities of over $60 \%$ in some locations (Eakin et al. 2010; Hughes et al. 2017). Predicted impacts of persistent bleaching events include a reduction of reef biodiversity and coral cover, up to the total extinction of local coral species (Brainard et al. 2011, 2013). Furthermore, ocean acidification decelerates the calcification of corals by reducing the concentration of carbonate $\left(\mathrm{CO}_{3}{ }^{2-}\right)$, and thus making it even less available for marine calcifiers (HoeghGuldberg et al. 2007). To counteract the fast and massive coral decline, a better understanding of the recovery and population dynamics of stony corals needs to be developed. because threatened coral reef systems depend on the recruitment of new individuals (Mumby and Steneck 2008). The recruitment process can be divided into (1) the development of competent larvae in the water column (spawners) or within the corals itself (brooders), (2) the settlement (searching, attachment, and larval metamorphosis) onto suitable substrata (Fig. 8.9), and (3) the survival of juvenile corals (Ritson-Williams et al. 2009). Since the survival rate of juvenile corals is likely influenced by the type of substratum chosen for settlement (Harrington et al. 2004; Ritson-Williams et al. 2010), finding a suitable settlement ground may be a critical step within the recruitment process.

Although chemical cues are believed to serve as the primary determinants of coral settlement, to some extent, physical properties have shown to influence coral larvae settlement as well. In a field study, larvae of five different species of scleractinian corals, including Goniastrea favulus, G. aspera, 
Acropora tenuis, Oxypora lacera, and Montipora peltiformis, have shown to favor locations with lower light intensity (Mundy and Babcock 1998). Also, a study by Mason et al. (2011) demonstrated that both larvae of Porites astreoides and Acropora palmata consistently settled on different red or redorange plastic materials while, at the same time, disdaining other colors such as green, blue, or white. It was suggested that this consistent response to red or reddish surfaces is related to long-wavelength photosensitivity and thus might be a potential strategy to artificially promote coral larvae settlement. Over the past decades, many studies have shown that coral larvae settle in response to either live CCA or organic extracts of CCA. For instance, larvae of the agariciid corals Agaricia tenuifolia, A. humilis, and A. agaricites have reported to settle to different degrees of stringency and specificity on Caribbean CCA, specifically Hydrolithon boergesenii. The responsible morphogenic inducer was fractionated by ultrafiltration and shown to be a water-insoluble, ether-insoluble, and acetoneinsoluble unstable biochemical, which is apparently associated with the cell walls of the inducing CCA (Morse et al. 1988). Further studies by Morse and Morse (1991) have shown that the inductive molecule is a sulfated glycosaminoglycan. A field study of Price (2010) showed that larvae of several scleractinian corals, including Pocillopora spp., Acropora spp., and Porites spp., do indeed prefer specific CCA species for in situ settlement, as they recruited more frequently on Titanoderma prototypum than on other CCA. A similar settlement specificity has been demonstrated for larvae of the scleractinian corals A. palmata and Montastraea faveolata. The latter two species have been tested for their rates of settlement on ten different species of red algae, including eight different CCA species, resulting in strong settlement preferences of larvae from both corals to different CCA. A. palmata settled on surfaces of $H$. boergesenii, Lithoporella atlantica, Neogoniolithon affine, and Titanoderma prototypum, but showed no settlement on $N$. mamillare. Larvae of $M$. faveolata settled on surfaces of Amphiroa tribulus, $H$. boergesenii, N. affine, N. munitum, and T. prototypum, but no settlement occurred on $N$. mamillare, Porolithon pachydermum, and a noncoralline Peyssonnelia sp. The authors of this study suggested that patterns of coral dis-

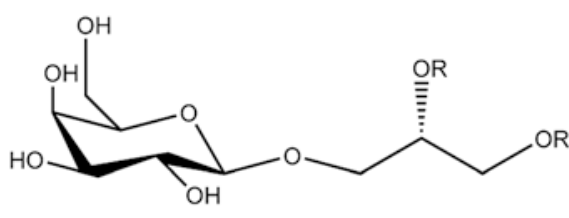

(a)

Fig. 8.10 Chemical structures of (a) (2S)-1-O-(7Z,10Z,13Z hexadecatrienoyl)-3-O- $\beta$-D-galactopyranosyl-sn-glycerol and (b) (2R)-1 tribution might be dependent on the red algae distribution (Ritson-Williams et al. 2014). However, in many cases of coral larvae settlement, the chemical identity of the presumed settlement-inducing molecule is just poorly described or remains largely unknown. In the past, the identity of these CCA-associated chemical cues was presumed to be cell wall-bound and thought to be some kind of high molecular mass polysaccharides (Morse and Morse 1991; Morse et al. 1994, 1996). Other studies chemically fully described the chemical signaling molecules; however, the detected cue often did not initiate the entire settlement cascade (e.g., 11-deoxyfistularin-3, Fig. 8.8d) (Kitamura et al. 2007) or just function as a settlement enhancer, such as luminaolide (Fig. 8.8e). The macrodiolide luminaolide was originally isolated from the CCA $H$. reinboldii and greatly enhanced the metamorphosis activity in Leptastrea purpurea when combined with another fraction that eluted at $80 \%$ aqueous methanol by octadecyl silica gel column chromatography (Kitamura et al. 2009; Maru et al. 2013). Interestingly, chemical inducers for larval settlement were also discovered in coral rubble and the skeleton of the massive coral Goniastrea sp. (Heyward and Negri 1999), indicating that coral larvae settlement can be either induced by a variety of chemical cues or by specific cues from multiple sources. In the past, bacterial biofilms have received notable attention as suitable settlement ground for many marine invertebrate larvae (Johnson et al. 1991; Pawlik 1992; Huang and Hadfield 2003; Huggett et al. 2006; Hadfield 2011). It was shown that coral reef biofilms, which were more than 2 weeks old, are able to induce settlement in the scleractinian A. microphthalma. FISH (fluorescence in situ hybridization) analysis revealed that the overall community composition of these biofilms was dominated by classes of Alphaproteobacteria, Betaproteobacteria, Gammaproteobacteria, and CytophagiaFlavobacteria of Bacteroidetes (Webster et al. 2004). Apart from bacterial multispecies biofilms, a specific strain belonging to the genus Pseudoalteromonas (Pseudoalteromonas A3) isolated from the CCA $H$. onkodes was able to induce full settlement, including attachment and metamorphosis, in the reef-building corals $A$. willisae and A. millepora

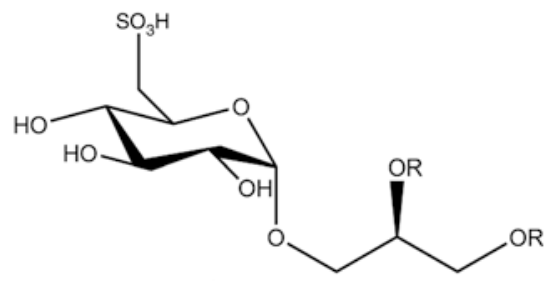

(b)

-O-(palmitoyl)-3-O- $\alpha$-D-(6'-sulfoquinovosyl)-sn-glycerol (Tebben et al. 2015) (created with ChemDraw, v. 16.0.1.4) 
(Negri et al. 2001). Another metamorphosis-inducing cue, named tetrabromopyrrole, was also isolated from a Pseudoalteromonas sp. (Tebben et al. 2011). This compound might have widespread importance among Caribbean corals as it induced settlement in the brooder Porites astreoides as well as in the spawning species Orbicella franksi and A. palmata (Sneed et al. 2014). Further studies on the ecological relevance of Pseudoalteromonads and tetrabromopyrrole in the coral settlement process revealed that the respective bacteria and its compound did not elicit the same rates of coral larvae settlement as CCA and instead introduced morphogenic processes that are often fatal to the larvae. Instead it was found that CCA-derived molecules, belonging to the chemical classes of glycoglycerolipids (Fig. 8.10a, b) and high molecular weight polysaccharides, are the major contributors of the mixed fractions and caused larval settlement at equivalent concentrations present in live CCA (Tebben et al. 2015).

\subsection{Conclusions}

Secondary metabolites are investigated for their outstanding pharmaceutical applications as well as for their ecological relevance. Many MNPs have been found to elicit a broad range of bioactivities and, therefore, continue to be a prolific source for the generation of new drugs or drug leads. We believe that the exploration of new and extreme habitats will advance the discovery of novel macro- and microorganisms and, thus, might lead to the detection and isolation of novel NPs. Specifically, marine fungi still represent an underestimated but rich source for new SMs, although their distribution and ecological role often remains scarce. The hyphenation of state-of-the-art techniques such as chromatographic separation, mass spectrometry, and nuclear magnetic resonance spectroscopy is a suitable way to facilitate NP screening effort. Particularly, the use of multiple secondary metabolite databases as well as MS/MS approaches in combination with molecular networking makes the search for novel NPs more efficient and, at the same time, lowers the risk of rediscovery. In terms of chemical ecology, SMs fulfill manifold roles for their producers. Besides predator-prey and algae-herbivore interactions, marine chemical ecology has also shifted its focus on marine invertebrate settlement behavior. Specifically, the role of SMs as signaling molecules for coral larvae settlement has gained interest during the last decades. CCA and their associated microorganisms are the best-known sources for coral larvae settlement cues, but until today, only few settlement compounds have been chemically fully described. Furthermore, the knowledge of the interplay between coral larva, settlement cue, settlement cue-producing organism (may it be the CCA or its associated microbes), and other environmental factors such as light intensity is still limited and needs to be improved for a deeper comprehension of coral reef functioning. We are only at the beginning of understanding the role of SMs in the marine environment and many fascinating discoveries are yet to come.

Acknowledgments This study was carried out in the framework of the $\mathrm{PhD}$ research training group "The Ecology of Molecules" (EcoMol) supported by the Lower Saxony Ministry for Science and Culture. We also thank the reviewers for valuable comments which helped to improve the manuscript.

\section{Appendix}

This article is related to the YOUMARES 9 conference session no. 9: "Biodiversity of Benthic Holobionts: Chemical Ecology and Natural Products Chemistry in the Spotlight." The original Call for Abstracts and the abstracts of the presentations within this session can be found in the Appendix "Conference Sessions and Abstracts", Chapter "7 Biodiversity of Benthic Holobionts: Chemical Ecology and Natural Products Chemistry in the Spotlight", of this book.

\section{References}

Ainsworth TD, Heron SF, Ortiz JC et al (2016) Climate change disables coral bleaching protection on the Great Barrier Reef. Science 352:338-342

Amend AS, Barshis DJ, Oliver TA (2012) Coral-associated marine fungi form novel lineages and heterogeneous assemblages. ISME J 6:1291-1301

Asolkar RN, Freel KC, Jensen PR et al (2009) Arenamides A-C, cytotoxic NFkB inhibitors from the marine actinomycete Salinispora Arenicola. J Nat Prod 72:396-402

Bai R, Pettit GR, Hamel E (1990) Dolastatin 10, a powerful cytostatic peptide derived from a marine animal. Inhibition of tubulin polymerization mediated through the vinca alkaloid binding domain. Biochem Pharmacol 39:1941-1949

Barbier EB, Hacker SD, Kennedy C et al (2011) The value of estuarine and coastal ecosystem services. Ecol Monogr 81:169-193

Bell JJ, Smith D (2004) Ecology of sponge assemblages (Porifera) in the Wakatobi region, south-east Sulawesi, Indonesia: richness and abundance. J Mar Biol Assoc UK 84:581-591

Bell JJ, Davy SK, Jones T et al (2013) Could some coral reefs become sponge reefs as our climate changes? Glob Change Biol 19:2613-2624

Bellwood DR, Hughes TP, Folke C et al (2004) Confronting the coral reed crisis. Nature 429:827-833

Bérdy J (2005) Bioactive microbial metabolites. A personal view. J Antibiot 58:1-26

Bergmann W, Burke DC (1955) Contributions to the study of marine products. XXXIX. The nucleosides of sponges. III. Spongothymidine and spongouridine. J Org Chem 20:1501-1507 
Bergmann W, Feeneyz RJ (1951) Contributions to the study of marine products. XXXII. The nucleosides of sponges. I. J Org Chem 16:981-987

Bhadury P, Mohammad BT, Wright PC (2006) The current status of natural products from marine fungi and their potential as antiinfective agents. J Ind Microbiol Biotechnol 33:325-337

Bianco ÉM, Teixeira VL, Pereira RC (2010) Chemical defenses of the tropical marine seaweed Canistrocarpus cervicornis against herbivory by sea urchin. Braz J Oceanogr 58:213-218

Bingham BL, Young CM (1991) Influence of sponges on invertebrate recruitment: a field test of allelopathy. Mar Biol 109:19-26

Blunt JW, Copp BR, Keyzers RA et al (2015) Marine natural products. Nat Prod Rep 32:116-211

Blunt JW, Carroll AR, Copp BR et al (2018) Marine natural products. Nat Prod Rep 35:8-53

Brainard RE, Birkeland C, Eakin CM et al (2011) Status review report of 82 candidate coral species petitioned under the U.S. endangered species act. U.S. Department of Commerce, NOAA Technical Memorandum, NOAA-TM-NMFS-PIFSC-27, $530 \mathrm{p}+1$ appendix

Brainard RE, Weijerman M, Eakin CM et al (2013) Incorporating climate and ocean change into extinction risk assessments for 82 coral species. Conserv Biol 27:1169-1178

Breinbauer R, Vetter IR, Waldmann H (2002) Von Proteindomänen zu Wirkstoffkandidaten - Naturstoffe als Leitstrukturen für das Design und die Synthese von Substanzbibliotheken. Angew Chem 114:3002-3015

Bugni TS, Ireland CM (2004) Marine-derived fungi: a chemically and biologically diverse group of microorganisms. Nat Prod Rep 21:143-163

Bull AT, Stach JEM (2007) Marine actinobacteria: new opportunities for natural product search and discovery. Trends Microbiol 15:491-499

Bull AT, Stach JEM, Ward AC et al (2005) Marine actinobacteria: perspectives, challenges, future directions. Antonie Van Leeuwenhoek 87:65-79

Burgaud G, Le Calvez T, Arzur D et al (2009) Diversity of culturable marine filamentous fungi from deep-sea hydrothermal vents. Environ Microbiol 11:1588-1600

Carrano L, Marinelli F (2015) The relevance of chemical dereplication in microbial natural product screening. J Appl Bioanal 1:55-67

Chevolot L, Cochard J-C, Yvin J-C (1991) Chemical induction of larval metamorphosis of Pecten maximus with a note on the nature of naturally occurring triggering substances. Mar Ecol Prog Ser 74:83-89

Clare AS, Matsumura K (2000) Nature and perception of barnacle settlement pheromones. Biofouling 15:57-71

Colvard NB, Edmunds PJ (2011) Decadal-scale changes in abundance of non-scleractinian invertebrates on a Caribbean coral reef. J Exp Mar Biol Ecol 397:153-160

Cooper MB, Smith AG (2015) Exploring mutualistic interactions between microalgae and bacteria in the omics age. Curr Opin Plant Biol 26:147-153

Craft JD, Paul VJ, Sotka EE (2013) Biogeographic and phylogenetic effects on feeding resistance of generalist herbivores toward plant chemical defenses. Ecology 94:18-24

Crisp DJ, Meadows PS (1962) The chemical basis of gregariousness in cirripedes. Proc R Soc Lond B Biol Sci 156:500-520

Crisp DJ, Meadows PS (1963) Adsorbed layers: the stimulus to settlement in barnacles. Proc R Soc Lond B Biol Sci 158:364-387

Cueto M, Jensen PR, Kauffman C et al (2001) Pestalone, a new antibiotic produced by a marine fungus in response to bacterial challenge. J Nat Prod 64:1444-1446

Da-Anoy JP, Villanueva RD, Cabaitan PC et al (2017) Effects of coral extracts on survivorship, swimming behavior, and settlement of Pocillopora damicornis larvae. J Exp Mar Biol Ecol 486:93-97

Das S, Lyla PS, Ajmal Khan S (2006) Marine microbial diversity and ecology: importance and future perspectives. Curr Sci 90:1325-1335 de Carvalho CCCR, Fernandes P (2010) Production of metabolites as bacterial responses to the marine environment. Mar Drugs 8:705-727

DeLong EF, Preston CM, Mincer T et al (2006) Community genomics among stratified microbial assemblages in the ocean's interior. Science 311:496-503

Dewick PM (2002) Medicinal natural products. A biosynthetic approach. Wiley, Chichester

Dias DA, Urban S, Roessner U (2012) A historical overview of natural products in drug discovery. Meta 2:303-336

Dreanno C, Matsumura K, Dohmae N et al (2006) An $\alpha 2$-macroglobulinlike protein is the cue to gregarious settlement of the barnacle Balanus amphitrite. Proc Natl Acad Sci U S A 103:14396-14401

Eakin CM, Morgan JA, Heron SF et al (2010) Caribbean corals in crisis: record thermal stress, bleaching, and mortality in 2005. PLoS One 5:e13969. https://doi.org/10.1371/journal.pone.0013969

Elbourne PD, Clare AS (2010) Ecological relevance of a conspecific, waterborne settlement cue in Balanus amphitrite (Cirripedia). J Exp Mar Biol Ecol 392:99-106

Endo N, Nogata Y, Yoshimura E et al (2009) Purification and partial amino acid sequence analysis of the larval settlement-inducing pheromone from adult extracts of the barnacle, Balanus amphitrite (= Amphibalanus amphitrite). Biofouling 25:429-434

Feling RH, Buchanan GO, Mincer TJ et al (2003) Salinosporamide A: a highly cytotoxic proteasome inhibitor from a novel microbial source, a marine bacterium of the new genus Salinospora. Angew Chem Int Ed 42:355-357

Fenical W (1999) Halimide, a cytotoxic marine natural product, and derivatives thereof. US Patent WO 1999048889 A1

Fenical W, Jensen PR (1993) Marine microorganisms: a new biomedical resource. In: Attaway DH, Zaborsky OR (eds) Marine biotechnology. Plenum Press, New York, pp 419-457

Fenical W, Jensen PR (2006) Developing a new resource for drug discovery: marine actinomycete bacteria. Nat Chem Biol 2:666-673

Fu P, Legako A, La S et al (2016) Discovery, characterization, and analogue synthesis of bohemamine dimers generated by non-enzymatic biosynthesis. Chem Eur J 22:3491-3495

Gademann K, Kobylinska J (2009) Antimalarial natural products of marine and freshwater origin. Chem Rec 9:187-198

Gerwick WH, Moore BS (2012) Lessons from the past and charting the future of marine natural products drug discovery and chemical biology. Chem Biol 19:85-98

Goecke F, Labes A, Wiese J et al (2010) Chemical interactions between marine macroalgae and bacteria. Mar Ecol Prog Ser 409:267-300

Goecke F, Labes A, Wiese J et al (2012) Dual effect of macroalgal extracts on growth of bacteria in Western Baltic Sea. Rev Biol Mar Oceanogr 47:75-86

Gomes NGM, Lefranc F, Kijjoa A et al (2015) Can some marinederived fungal metabolites become actual anticancer agents? Mar Drugs 13:3950-3991

Goodfellow M, Fiedler H-P (2010) A guide to successful bioprospecting: informed by actinobacterial systematics. Antonie Van Leeuwenhoek 98:119-142

Guijas C, Montenegro-Burke JR, Domingo-Almenara X et al (2018) Metlin: a technology platform for identifying knowns and unknowns. Anal Chem 90:3156-3164

Gulder TAM, Moore BS (2009) Chasing the treasures of the sea - bacterial marine natural products. Curr Opin Microbiol 12:252-260

Gullo VP, McAlpine J, Lam KS et al (2006) Drug discovery from natural products. J Ind Microbiol Biotechnol 33:523-531

Gurnani N, Mehta D, Gupta M et al (2014) Natural products: source of potential drugs. Afr J Basic Appl Sci 6:171-186

Haber M, Carbone M, Mollo E et al (2011) Chemical defense against predators and bacterial fouling in the Mediterranean sponges Axinella polypoides and A. verrucosa. Mar Ecol Prog Ser 422:113-122 
Hadfield MG (2011) Biofilms and marine invertebrate larvae: what bacteria produce that larvae use to choose settlement sites. Annu Rev Mar Sci 3:453-470

Hadfield MG, Paul VJ (2001) Natural chemical cues for settlement and metamorphosis of marine-invertebrate larvae. In: McClintock JB, Baker BJ (eds) Marine chemical ecology. CRC Press, Boca Raton, pp 431-461

Haefner B (2003) Drugs from the deep: marine natural products as drug candidates. Drug Discov Today 8:536-544

Harder T, Campbell AH, Egan S et al (2012) Chemical mediation of ternary interactions between marine holobionts and their environment as exemplified by the red alga Delisea pulchra. J Chem Ecol $38: 442-450$

Harder T, Tebben J, Möller M et al (2018) Chemical ecology of marine invertebrate larval settlement. In: Puglisi M, Becerro MA (eds) Chemical ecology: the ecological impact of marine natural products. CRC Press, Boca Raton, pp 328-355

Harrington L, Fabricius K, De'ath G et al (2004) Recognition and selection of settlement substrata determine post-settlement survival in corals. Ecology 85:3428-3437

Hay ME (1996) Marine chemical ecology: what's known and what's next? J Exp Mar Bio Ecol 200:103-134

Hay ME (2009) Marine chemical ecology: chemical signals and cues structure marine populations, communities, and ecosystems. Annu Rev Mar Sci 1:193-212

Heilmann J (2007) Wirkstoffe auf Basis biologisch aktiver Naturstoffe. Chem unserer Zeit 41:376-389

Helber SB, de Voogd NJ, Muhando CA et al (2017) Anti-predatory effects of organic extracts of 10 common reef sponges from Zanzibar. Hydrobiologia 790:247-258

Helber SB, Hoeijmakers DJJ, Muhando CA et al (2018) Sponge chemical defenses are a possible mechanism for increasing sponge abundance on reefs in Zanzibar. PLoS One 13:e0197617. https://doi. org/10.1371/journal.pone.0197617

Hellio C, Tsoukatou M, Maréchal J-P et al (2005) Inhibitory effects of Mediterranean sponge extracts and metabolites on larval settlement of the barnacle Balanus amphitrite. Mar Biotechnol 7:297-305

Henríquez M, Vergara K, Norambuena J et al (2014) Diversity of cultivable fungi associated with Antarctic marine sponges and screening for their antimicrobial, antitumoral and antioxidant potential. World J Microbiol Biotechnol 30:65-76

Hentschel U, Piel J, Degnan SM et al (2012) Genomic insights into the marine sponge microbiome. Nat Rev Microbiol 10:641-654

Heron SF, Maynard JA, van Hooidonk R et al (2016) Warming trends and bleaching stress of the world's coral reefs 1985-2012. Sci Rep 6:38402. https://doi.org/10.1038/srep38402

Heyward AJ, Negri AP (1999) Natural inducers for coral larval metamorphosis. Coral Reefs 18:273-279

Hoegh-Guldberg O, Mumby PJ, Hooten AJ et al (2007) Coral reefs under rapid climate change and ocean acidification. Science 318:1737-1742

Hu Y, Chen J, Hu G et al (2015) Statistical research on the bioactivity of new marine natural products discovered during the 28 years from 1985 to 2012. Mar Drugs 13:202-221

Huang S, Hadfield MG (2003) Composition and density of bacterial biofilms determine larval settlement of the polychaete Hydroides elegans. Mar Ecol Prog Ser 260:161-172

Hubert J, Nuzillard J-M, Renault J-H (2017) Dereplication strategies in natural product research: how many tools and methodologies behind the same concept? Phytochem Rev 16:55-95

Hug LA, Baker BJ, Anantharaman K et al (2016) A new view of the tree of life. Nat Commun 7:11870. https://doi.org/10.1038/ nmicrobiol.2016.48

Huggett MJ, Williamson JE, de Nys R et al (2006) Larval settlement of the common Australian sea urchin Heliocidaris erythrogramma in response to bacteria from the surface of coralline algae. Oecologia 149:604-619

Hughes CC, Fenical W (2010) Antibacterials from the sea. Chem Eur J 16:12512-12525

Hughes TP, Kerry JT, Álvarez-Noriega M et al (2017) Global warming and recurrent mass bleaching of corals. Nature 543:373-377

Imhoff JF, Labes A, Wiese J (2011) Bio-mining the microbial treasures of the ocean: new natural products. Biotechnol Adv 29:468-482

Jensen PR, Mincer TJ, Williams PG et al (2005) Marine actinomycete diversity and natural product discovery. Antonie Van Leeuwenhoek 87:43-48

Johnson CR, Sutton DC, Olson RR et al (1991) Settlement of crownof-thorns starfish: role of bacteria on surfaces of coralline algae and a hypothesis for deepwater recruitment. Mar Ecol Prog Ser $71: 143-162$

Jones EBG (2011) Fifty years of marine mycology. Fungal Divers 50:73-112

Kazamia E, Czesnick H, Van Nguyen TT et al (2012) Mutualistic interactions between vitamin $\mathrm{B}_{12}$-dependent algae and heterotrophic bacteria exhibit regulation. Environ Microbiol 14:1466-1476

Keller NP, Turner G, Bennett JW (2005) Fungal secondary metabolism. From biochemistry to genomics. Nat Rev Microbiol 3:937-947

Kind T, Tsugawa H, Cajka T et al (2017) Identification of small molecules using accurate mass MS/MS search. Mass Spec Rev 37:513-532

Kitamura M, Koyama T, Nakano Y et al (2007) Characterization of a natural inducer of coral larval metamorphosis. J Exp Mar Bio Ecol 340:96-102

Kitamura M, Schupp PJ, Nakano Y et al (2009) Luminaolide, a novel metamorphosis-enhancing macrodiolide for scleractinian coral larvae from crustose coralline algae. Tetrahedron Lett 50:6606-6609

Kohlmeyer J, Kohlmeyer E (1979) Marine mycology. The higher fungi. Academic, New York

Kreis W (2007) Prinzipien des Sekundärstoffwechsels. In: Hänsel R, Sticher O (eds) Pharmakognosie - Phytopharmazie. Springer, Heidelberg, pp 4-30

Kreysa G, Grabley S (2007) Vorbild Natur. Stand und Perspektiven der Naturstoff-Forschung in Deutschland. DECHEMA e.V., Frankfurt am Main

Kubicek A, Bessho K, Nakaoka M et al (2011) Inducible defence and its modulation by environmental stress in the red alga Chondrus yendoi (Yamada and Mikami in Mikami, 1965) from Honshu Island, Japan. J Exp Mar Bio Ecol 397:208-213

Kurita KL, Linington RG (2015) Connecting phenotype and chemotype: high-content discovery strategies for natural products research. J Nat Prod 78:587-596

Kwon HC, Kauffman CA, Jensen PR et al (2006) Marinomycins A-D, antitumor-antibiotics of a new structure class from a marine actinomycete of the recently discovered genus "Marinispora". J Am Chem Soc 128:1622-1632

Lachnit T, Blümel M, Imhoff JF et al (2009) Specific epibacterial communities on macroalgae: phylogeny matters more than habitat. Aquat Biol 5:181-186

Lau SCK, Qian P-Y (2001) Larval settlement in the serpulid polychaete Hydroides elegans in response to bacterial films: an investigation of the nature of putative larval settlement cue. Mar Biol 138:321-328

Lau SCK, Thiyagarajan V, Cheung SCK et al (2005) Roles of bacterial community composition in biofilms as a mediator for larval settlement of three marine invertebrates. Aquat Microb Ecol 38:41-51

Le TC, Yang I, Yoon YJ (2016) Ansalactams B-D illustrate further biosynthetic plasticity within the ansamycin pathway. Org Lett 18:2256-2259

Lee OO, Wong YH, Qian P-Y (2009) Inter- and intraspecific variations of bacterial communities associated with marine sponges from San Juan Island, Washington. Appl Environ Microbiol 75:3513-3521 
Lee J-Y, Orlikova B, Diederich M (2015) Signal transducers and activators of transcription (STAT) regulatory networks in marine organisms: from physiological observations towards marine drug discovery. Mar Drugs 13:4967-4984

Letzel A-C, Pidot SJ, Hertweck C (2013) A genomic approach to the cryptic secondary metabolome of the anaerobic world. Nat Prod Rep 30:392-428

Li W, Scott AP, Siefkes MJ et al (2002) Bile acid secreted by male sea lamprey that acts as a sex pheromone. Science 296:138-141

Loh T-L, Pawlik JR (2014) Chemical defenses and resource trade-offs structure sponge communities on Caribbean coral reefs. Proc Natl Acad Sci U S A 111:4151-4156

Lonsdale DJ, Frey MA, Snell TW (1998) The role of chemical signals in copepod reproduction. J Mar Syst 15:1-12

Loque CP, Medeiros AO, Pellizzari FM et al (2010) Fungal community associated with marine macroalgae from Antarctica. Polar Biol 33:641-648

Ludwig-Müller J, Gutzeit H (2014) Biologie von Naturstoffen. Synthese, biologische Funktionen und Bedeutung für die Gesundheit. UTB, Stuttgart

Luesch H, Moore RE, Paul VJ et al (2001) Isolation of dolastatin 10 from the marine cyanobacterium Symploca species VP642 and total stereochemistry and biological evaluation of its analogue symplostatin 1. J Nat Prod 64:907-910

Macheleidt J, Mattern DJ, Fischer J et al (2016) Regulation and role of fungal secondary metabolites. Annu Rev Genet 50:371-392

Madigan MT, Martinko JM, Parker J (2003) Brock biology of microorganisms. Prentice Hall, Upper Saddle River

Maliao RJ, Turingan RG, Lin J (2008) Phase-shift in coral reef communities in the Florida keys National Marine Sanctuary (FKNMS), USA. Mar Biol 154:841-853

Martins A, Vieira H, Gaspar H et al (2014) Marketed marine natural products in the pharmaceutical and cosmeceutical industries: tips for success. Mar Drugs 12:1066-1101

Maru N, Inuzuka T, Yamamoto K et al (2013) Relative configuration of luminaolide. Tetrahedron Lett 54:4385-4387

Mason B, Beard M, Miller MW (2011) Coral larvae settle at a higher frequency on red surfaces. Coral Reefs 30:667-676

Matsumura K, Nagano M, Fusetani N (1998) Purification of a larval settlement-inducing protein complex (SIPC) of the barnacle, Balanus amphitrite. J Exp Zool 281:12-20

Mayer AMS, Glaser KB, Cuevas C (2010) The odyssey of marine pharmaceuticals: a current pipeline perspective. Trends Pharmacol Sci 31:255-265

Mayer AMS, Rodríguez AD, Taglialatela-Scafati O et al (2013) Marine pharmacology in 2009-2011: marine compounds with antibacterial, antidiabetic, antifungal, anti-inflammatory, antiprotozoal, antituberculosis, and antiviral activities; affecting the immune and nervous systems, and other miscellaneous mechanisms of action. Mar Drugs 11:2510-2573

Moberg F, Folke C (1999) Ecological goods and services of coral reef ecosystems. Ecol Econ 29:215-233

Mohamed A, Nguyen CH, Mamitsuka H (2016) Current status and prospects of computational resources for natural product dereplication: a review. Brief Bioinform 17:309-321

Moitinho-Silva L, Nielsen S, Amir A et al (2017) The sponge microbiome project. Gigascience 6:1-7

Molinski TF, Dalisay DS, Lievens SL et al (2009) Drug development from marine natural products. Nat Rev Drug Discov 8:69-85

Morse DE, Morse ANC (1991) Enzymatic characterization of the morphogen recognized by Agaricia humilis (scleractinian coral) larvae. Biol Bull 181:104-122

Morse DE, Hooker N, Morse ANC et al (1988) Control of larval metamorphosis and recruitment in sympatric agariciid coral. J Exp Mar Bio Ecol 116:193-217
Morse DE, Morse ANC, Raimondi PT et al (1994) Morphogen-based chemical flypaper for Agaricia humilis coral larvae. Biol Bull 186:172-181

Morse ANC, Iwao K, Baba M et al (1996) An ancient chemosensory mechanism brings new life to coral reefs. Biol Bull 191:149-154

Mumby PJ, Steneck RS (2008) Coral reef management and conservation in light of rapidly evolving ecological paradigms. Trends Ecol Evol 23:555-563

Mundy CN, Babcock RC (1998) Role of light intensity and spectral quality in coral settlement: implications for depth-dependent settlement? J Exp Mar Bio Ecol 223:235-255

Nastrucci C, Cesario A, Russo P (2012) Anticancer drug discovery from the marine environment. Recent Pat Anticancer Drug Discov 7:218-232

Negri AP, Webster NS, Hill RT (2001) Metamorphosis of broadcast spawning corals in response to bacteria isolated from crustose algae. Mar Ecol Prog Ser 223:121-131

Nicolas L, Robert R, Chevolot L (1998) Comparative effects of inducers on metamorphosis of the Japanese oyster Crassostrea gigas and the great scallop Pecten maximus. Biofouling 12:189-203

Nielsen KF, Månsson M, Rank C et al (2011) Dereplication of microbial natural products by LC-DAD-TOFMS. J Nat Prod 74:2338-2348

Noyer C, Becerro MA (2012) Relationship between genetic, chemical, and bacterial diversity in the Atlanto-Mediterranean bath sponge Spongia lamella. Hydrobiologia 687:85-99

Noyer C, Thomas OP, Becerro MA (2011) Patterns of chemical diversity in the Mediterranean sponge Spongia lamella. PLoS One 6:e20844. https://doi.org/10.1371/journal.pone.0020844

O'Brien J, Wright GD (2011) An ecological perspective of microbial secondary metabolism. Curr Opin Biotechnol 22:552-558

Okazaki T, Kitahara T, Okami Y (1975) Studies on marine microorganisms. IV. A new antibiotic SS-228 Y produced by Chainia isolated from shallow sea mud. J Antibiot 28:176-184

Ortlepp S, Sjögren M, Dahlström M et al (2006) Antifouling activity of bromotyrosine-derived sponge metabolites and synthetic analogues. Mar Biotechnol 9:776-785

Overy DP, Bayman P, Kerr RG et al (2014) An assessment of natural product discovery from marine (sensu strictu) and marine-derived fungi. Mycology 5:145-167

Pantazopoulou A, Galmarini CM, Penalva MA (2018) Molecular basis of resistance to the microtubule-depolymerizing antitumor compound plocabulin. Sci Rep 8:8616. https://doi.org/10.1038/ s41598-018-26736-3

Paul VJ, Ritson-Williams R, Sharp K (2011) Marine chemical ecology in benthic environments. Nat Prod Rep 28:345-387

Paul VJ, Ritson-Williams R, Campbell J et al (2014) Algal chemical ecology in a changing ocean. Planta Med 80:IL11. https://doi.org/1 $0.1055 / \mathrm{s}-0034-1382302$

Pauly D, Christensen V, Guénette S et al (2002) Towards sustainability in world fisheries. Nature 418:689-695

Pawlik JR (1986) Chemical induction of larval settlement and metamorphosis in the reef-building tube worm Phragnmtopoma californica (Sabellariidae: Polychaeta). Mar Biol 91:59-68

Pawlik JR (1992) Chemical ecology of the settlement of benthic marine invertebrates. Oceanogr Mar Biol 30:273-335

Pawlik JR (2011) The chemical ecology of sponges on Caribbean reefs: natural products shape natural systems. Bioscience 61:888-898

Pawlik JR, Steindler L (2007) Chemical warfare on coral reefs: sponge metabolites differentially affect coral symbiosis in situ. Limnol Oceanogr 52:907-911

Pawlik JR, Butman CA, Starczak VR (1991) Hydrodynamic facilitation of gregarious settlement of a reef-building tube worm. Science 251:421-424

Pérez MJ, Falqué E, Domínguez H (2016) Antimicrobial action of compounds from marine seaweed. Mar Drugs 14:52. https://doi. org/10.3390/md14030052 
Perry CT, Murphy GN, Kench PS et al (2013) Caribbean-wide decline in carbonate production threatens coral reef growth. Nat Commun 4:1402. https://doi.org/10.1038/ncomms 2409

Pichersky E, Gang DR (2000) Genetics and biochemistry of secondary metabolites in plants: an evolutionary perspective. Trends Plant Sci 5:439-445

Pohnert G (2004) Chemical defense strategies of marine organisms. Top Curr Chem 239:179-219

Pontius A, Krick A, Kehraus S et al (2008) Antiprotozoal activities of heterocyclic-substituted xanthones from the marine-derived fungus Chaetomium sp. J Nat Prod 71:1579-1584

Price N (2010) Habitat selection, facilitation, and biotic settlement cues affect distribution and performance of coral recruits in French Polynesia. Oecologia 163:747-758

Proksch P (1994) Defensive roles for secondary metabolites from marine sponges and sponge-feeding nudibranchs. Toxicon 32:639-655

Proksch P, Edrada-Ebel R, Ebel R (2006) Bioaktive Naturstoffe aus marinen Schwämmen: Apotheke am Meeresgrund. Biol unserer Zeit 36:150-159

Puglisi MP, Sneed JM, Sharp K et al (2014) Marine chemical ecology in benthic environments. Nat Prod Rep 31:1510-1553

Quinn RA, Nothias L-F, Vining O (2017) Molecular networking as a drug discovery, drug metabolism, and precision medicine strategy. Trends Pharmacol Sci 38:143-154

Radjasa OK, Vaske YM, Navarro G et al (2011) Highlights of marine invertebrate-derived biosynthetic products: their biomedical potential and possible production by microbial associants. Bioorg Med Chem 19:6658-6674

Rahman H, Austin B, Mitchell WJ et al (2010) Novel anti-infective compounds from marine bacteria. Mar Drugs 8:498-518

Rasher DB, Hoey AS, Hay M (2013) Consumer diversity interacts with prey defenses to drive ecosystem function. Ecology 94:1347-1358

Rateb ME, Ebel R (2011) Secondary metabolites of fungi from marine habitats. Nat Prod Rep 28:290-344

Ritson-Williams R, Arnold SN, Fogarty ND et al (2009) New perspectives on ecological mechanisms affecting coral recruitment on reefs. Smithson Contrib Mar Sci (38):437-457

Ritson-Williams R, Paul VJ, Arnold SN et al (2010) Larval settlement preferences and post-settlement survival of the threatened Caribbean corals Acropora palmata and A. cervicornis. Coral Reefs 29:71-81

Ritson-Williams R, Arnold SN, Paul VJ et al (2014) Larval settlement preferences of Acropora palmata and Montastraea faveolata in response to diverse red algae. Coral Reefs 33:59-66

Rohde S, Schupp PJ (2018) Spatial and temporal variability in sponge chemical defense. In: Puglisi M, Becerro MA (eds) Chemical ecology: the ecological impact of marine natural products. CRC press, Boca Raton, pp 372-397

Rohde S, Gochfeld DJ, Ankisetty S et al (2012) Spatial variability in secondary metabolites of the Indo-Pacific sponge Stylissa massa. J Chem Ecol 38:463-475

Rohde S, Nietzer S, Schupp PJ (2015) Prevalence and mechanisms of dynamic chemical defenses in tropical sponges. PLoS One 10:e0132236. https://doi.org/10.1371/journal.pone.0132236

Sakata K (1989) Feeding attractants and stimulants for marine gastropods. In: Scheuer PJ (ed) Bioorganic marine chemistry. Springer, Heidelberg, pp 115-129

Schulz B, Draeger S, de la Cruz TE et al (2008) Screening strategies for obtaining novel, biologically active, fungal secondary metabolites from marine habitats. Bot Mar 51:219-234

Schupp PJ, Paul VJ (1994) Calcium carbonate and secondary metabolites in tropical seaweeds: variable effects on herbivorous fishes. Ecology 75:1172-1185

Schwartz N, Rohde S, Hiromori S et al (2016) Understanding the invasion success of Sargassum muticum: herbivore preferences for native and invasive Sargassum spp. Mar Biol 163:181. https://doi org/10.1007/s00227-016-2953-4
Schwartz N, Rohde S, Dobretsov S et al (2017) The role of chemical antifouling defence in the invasion success of Sargassum muticum: a comparison of native and invasive brown algae. PLoS One 12:e0189761. https://doi.org/10.1371/journal.pone.0189761

Sebens KP (1983) Settlement and metamorphosis of a temperate softcoral larva (Alcyonium siderium Verrill): induction by crustose algae. Biol Bull 165:286-304

Sieg RD, Poulson-Ellestad KL, Kubanek J (2011) Chemical ecology of the marine plankton. Nat Prod Rep 28:388-399

Simmons TL, Andrianasolo E, McPhail K et al (2005) Marine natural products as anticancer drugs. Mol Cancer Ther 4:333-342

Simões MF, Antunes A, Ottoni CA et al (2015) Soil and rhizosphere associated fungi in gray mangroves (Avicennia marina) from the Red Sea - a metagenomic approach. Genomics Proteomics Bioinformatics 13:310-320

Simon C, Daniel R (2009) Achievements and new knowledge unraveled by metagenomic approaches. Appl Microbiol Biotechnol $85: 265-276$

Simon C, Daniel R (2011) Metagenomic analyses: past and future trends. Appl Environ Microbiol 77:1153-1161

Sneed JM, Sharp KH, Ritchie KB et al (2014) The chemical cue tetrabromopyrrole from a biofilm bacterium induces settlement of multiple Caribbean corals. Proc R Soc Lond B Biol Sci 281:20133086. https://doi.org/10.1098/rspb.2013.3086

Stanley GD Jr (2006) Photosymbiosis and the evolution of modern coral reefs. Science 312:857-858

Staufenberger T, Thiel V, Wiese J et al (2008) Phylogenetic analysis of bacteria associated with Laminaria saccharina. FEMS Microbiol Ecol 64:65-77

Swanson RL, Williamson JE, De Nys R et al (2004) Induction of settlement of larvae of the sea urchin Holopneustes purpurascens by histamine from a host alga. Biol Bull 206:161-172

Taori K, Paul VJ, Luesch H (2008) Structure and activity of largazole, a potent antiproliferative agent from the Floridian marine cyanobacterium Symploca sp. J Am Chem Soc 130:1806-1807

Tebben J, Tapiolas DM, Motti CA et al (2011) Induction of larval metamorphosis of the coral Acropora millepora by tetrabromopyrrole isolated from a Pseudoalteromonas bacterium. PLoS One 6:e19082. https://doi.org/10.1371/journal.pone.0019082

Tebben J, Motti CA, Siboni N et al (2015) Chemical mediation of coral larval settlement by crustose coralline algae. Sci Rep 5:10803. https://doi.org/10.1038/srep10803

Thiel V, Neulinger SC, Staufenberger T et al (2007) Spatial distribution of sponge-associated bacteria in the Mediterranean sponge Tethya aurantium. FEMS Microbiol Ecol 59:47-63

Thomas T, Moitinho-Silva L, Lurgi M et al (2016) Diversity, structure and convergent evolution of the global sponge microbiome. Nat Commun 7:11870. https://doi.org/10.1038/ncomms11870

Thompson JE (1985) Exudation of biologically-active metabolites in the sponge Aplysina fistularis. I. Biological evidence. Mar Biol $88: 23-26$

Thompson JE, Walker RP, Faulkner DJ (1985) Screening and bioassays for biologically-active substances from forty marine sponge species from San Diego, California, USA. Mar Biol 88:11-21

Thorson G (1950) Reproduction and larval ecology of marine bottom invertebrates. Biol Rev Camb Philos Soc 25:1-45

Toonen RJ, Pawlik JR (1996) Settlement of the tube worm Hydroides dianthus (Polychaeta: Serpulidae): cues for gregarious settlement. Mar Biol 126:725-733

Tsukamoto S, Kato H, Hirota H et al (1999) Lumichrome. A larval metamorphosis-inducing substance in the ascidian Halocynthia roretzi. Eur J Biochem 264:785-789

Villamizar E, Díaz MC, Rützler K et al (2013) Biodiversity, ecological structure, and change in the sponge community of different geomorphological zones of the barrier fore reef at Carrie Bow Cay, Belize. Mar Ecol 35:425-435 
Wang M-H, Li X-M, Li C-S et al (2013) Secondary metabolites from Penicillium pinophilum SD-272, a marine sediment-derived fungus. Mar Drugs 11:2230-2238

Wang Y-Z, Xue Y-R, Liu C-H (2015) A brief review of bioactive metabolites derived from deep-sea fungi. Mar Drugs 13:4594-4616

Wang M, Carver JJ, Phelan VV et al (2016) Sharing and community curation of mass spectrometry data with GNPS. Nat Biotechnol 34:828-837

Waters AL, Hill RT, Place AR et al (2010) The expanding role of marine microbes in pharmaceutical development. Curr Opin Biotechnol 21:780-786

Webster NS, Smith LD, Heyward AJ et al (2004) Metamorphosis of a scleractinian coral in response to microbial biofilms. Appl Environ Microbiol 70:1213-1221

Wiese J, Ohlendorf B, Blümel M et al (2011) Phylogenetic identification of fungi isolated from the marine sponge Tethya aurantium and identification of their secondary metabolites. Mar Drugs 9:561-585

Williams PG (2009) Panning for chemical gold: marine bacteria as a source of new therapeutics. Trends Biotechnol 27:45-52
Williams PG, Buchanan GO, Feling RH et al (2005) New cytotoxic salinosporamides from the marine actinomycete Salinispora tropica. J Org Chem 70:6196-6203

Williamson JE, De Nys R, Kumar N et al (2000) Induction of metamorphosis in the sea urchin Holopneustes purpurascens by a metabolite complex from the algal host Delisea pulchra. Biol Bull 198:332-345

Wilson MC, Nam S-J, Gulder TAM (2011) Structure and biosynthesis of the marine streptomycete ansamycin ansalactam A and its distinctive branched chain polyketide extender unit. J Am Chem Soc 133:1971-1977

Wolfender J-L, Marti G, Queiroz EF (2010) Advances in techniques for profiling crude extracts and for the rapid identification of natural products: dereplication, quality control and metabolomics. Curr Org Chem 14:1808-1832

Yvin JC, Chevolot L, Chevolot-Magueur AM et al (1985) First isolation of jacaranone from an alga, Delesseria sanguinea, a metamorphosis inducer of Pecten larvae. J Nat Prod 48:814-816

Open Access This chapter is licensed under the terms of the Creative Commons Attribution 4.0 International License (http://creativecommons. org/licenses/by/4.0/), which permits use, sharing, adaptation, distribution and reproduction in any medium or format, as long as you give appropriate credit to the original author(s) and the source, provide a link to the Creative Commons license and indicate if changes were made.

The images or other third party material in this chapter are included in the chapter's Creative Commons license, unless indicated otherwise in a credit line to the material. If material is not included in the chapter's Creative Commons license and your intended use is not permitted by statutory regulation or exceeds the permitted use, you will need to obtain permission directly from the copyright holder. 